\title{
28. ALTERATION OF BASALTS FROM THE WEST PACIFIC GUYOTS, LEGS 143 AND 144
}

\author{
V. Kurnosov, ${ }^{2}$ B. Zolotarev, ${ }^{2}$ V. Eroshchev-Shak, ${ }^{2}$ A. Artamonov, ${ }^{2}$ G. Kashinzev, ${ }^{3}$ and I. Murdmaa ${ }^{3}$
}

\begin{abstract}
Volcanic rocks recovered during Legs 143 and 144 on the Allison, Resolution, Lo-En, Wodejebato, and MIT guyots belong to intraplate alkaline basalts. The basalts are strongly altered by hydrothermal processes, and some are affected by subaerial weathering. The low-temperature hydrothermal alteration, which is best represented in inner parts of sills on the Allison Guyot, led mainly to the formation of smectite, swelling chlorite, mixed-layer smectite-chlorite, and carbonates. Kaolinite, smectite, and hematite dominate among the subaerial weathering products of basalts on the Resolution Guyot and occur in the outer zones of sills on the Allison Guyot. The basalts from the Lo-En, Wodejebato, and MIT guyots have undergone low-temperature smectitization. Formation of mixed-layer smectite-chlorite and serpentine is a result of high magnesium content in the primary basalt rather than of higher temperature.
\end{abstract}

\section{INTRODUCTION}

Active volcanic seamounts have favorable conditions for hydrothermal circulation and represent open convective cells. Necessary conditions for development of a hydrothermal circulation system within a seamount are a heat source in its central part, porosity of basalts, and large surface area of volcanic edifice in contact with seawater that can readily penetrate the seamount. In extinct volcanoes, we can expect a "frozen" hydrothermal system to be represented by altered basalts having vesicle infills and veins composed of alteration products.

The concentric style of temperature distribution in active volcanoes, caused by the presence of magma conduit in their central parts, creates different zones of alteration. The degree of basalt alteration typically increases from the flanks of a volcanic cone toward the central near-vent areas. The near-vent zone is assumed to suffer greater alteration as compared with the marginal zones. Basalts on the flanks of volcanic edifices are altered under oxidizing conditions as a result of interaction with oxygenated seawater, similar to that found on the mid-oceanic ridge flanks where flows of seawater descend into the crust (Bass et al., 1973; Bass, 1976; Kurnosov, 1986). The igneous rock alteration in the inner parts of volcanic edifices most likely occurs under "anoxic" conditions similar to those that occur in the axial parts of mid-oceanic ridges, where upward fluid flows are predominant ("nonoxidation" conditions; Bass, 1976).

Hydrothermal alteration processes in the volcanic seamounts may supply oceanic water with considerable amounts of dissolved elements. Estimation of the chemical element balance in the system of low-temperature water-rock interaction, for the Emperor Seamount Chain (Deep Sea Drilling Project [DSDP] Leg 55), confirms this hypothesis (Kurnosov, 1986).

This model needs to be verified and developed using new data. The goal of this paper is to present new mineralogical and geochemi-

\footnotetext{
${ }^{1}$ Haggerty, J.A., Premoli Silva, L., Rack, F., and McNutt, M.K. (Eds.), 1995. Proc. ODP, Sci. Results, 144: College Station, TX (Ocean Drilling Program).

${ }^{2}$ Geological Institute, Russian Academy of Sciences, Pyzhevsky Pereylok 7, Moscow 109017, Russian Federation.

${ }^{3}$ P.P. Shrishov Institute of Oceanology, Russian Academy of Sciences, Krasikova Street 23, Moscow 117218, Russian Federation.
}

cal data, obtained during our study of altered basalts from the West Pacific Guyots, on basalt alteration in the intraplate volcanoes.

\section{SITES AND SETTINGS \\ Site 865 (Allison Guyot)}

Allison Guyot (Leg 143, Site 865) is located in the central part of the Mid-Pacific Mountains (Sager, Winterer, Firth, et al., 1993). Hole $865 \mathrm{~A}$, at a water depth of $1518.4 \mathrm{~m}$, penetrated 870.9 meters below seafloor (mbsf): $139 \mathrm{~m}$ of pelagic sediments ranging from mid-Paleocene to Quaternary in age, $698 \mathrm{~m}$ of upper Albian shallow-water limestone, and $33 \mathrm{~m}$ of alkaline basalt. Basalts (sills) alternating with limestone were recovered below $831.8 \mathrm{mbsf}$. All of the basalt units belong to a single intrusive body.

\section{Site 866 (Resolution Guyot)}

Resolution Guyot is located $716 \mathrm{~km}$ northwest of Site 865 (Leg 143), in the western Mid-Pacific Mountains (Sager, Winterer, Firth, et al., 1993). Igneous rocks were recovered in Hole 866 A, which is located on the north edge of the guyot. The hole, at a water depth of $1346 \mathrm{~m}$, penetrated 1743.6 mbsf: $1620 \mathrm{~m}$ of Barremian to Albian shallow-water limestone overlying $123.6 \mathrm{~m}$ of basalt. The basalts (lavas of intraplate tholeiitic to alkaline compositions) are subaerial and moderately to very strongly altered. The average thickness of the flows is about $10 \mathrm{~m}$ (ranging from 4 to $26 \mathrm{~m}$ ). Subaerial weathering of basalts leads to development of lateritic soils.

\section{Site 872 (Lo-En Guyot)}

Lo-En Guyot (Leg 144, Site 872) is located in the northern Marshall Islands (Premoli Silva, Haggerty, Rack, et al., 1993). Hole 872B, at a water depth of $1083.6 \mathrm{~m}$, penetrated $192.5 \mathrm{mbsf}$ : washed to $77 \mathrm{mbsf}$ and from 106 to $135 \mathrm{mbsf}$; nannofossil-foraminifer ooze (middle to early Miocene) from 77.3 to 106.3 mbsf; numerous fragments of phosphatized chalk and limestone, manganese crusts, and volcaniclastic sandstones (age was not determined) from 135.2 to 135.36 mbsf; phosphatic pebbles underlain by limestone with basalt clasts (late Santonian) from 135.36 to $135.41 \mathrm{mbsf}$; and basalt (early Santonian or older) from 135.4 to $192.5 \mathrm{mbsf}$ (about $57 \mathrm{~m}$ ). Igneous rocks are represented by differentiated alkaline olivine basalt as massive flows and flow-top breccias. The latter suggest that these flows erupted subaerially in a short time, which precluded soil development on top of the flows. 


\section{Sites 874, 875, and 876 (Wodejebato Guyot)}

Wodejebato Guyot (Leg 144) is located 44 km northwest of Pikinni Atoll, in the Ralik Chain in the northern Marshall Islands (Premoli Silva, Haggerty, Rack, et al., 1993).

Hole 874B (inner perimeter ridge), at a water depth of $1374.9 \mathrm{~m}$, penetrated $193.5 \mathrm{mbsf}: 0.11 \mathrm{~m}$ of manganese crust and manganesephosphate coated limestone conglomerate (Maastrichtian to middle Eocene); $162.7 \mathrm{~m}$ of rudist-algal-foraminiferal limestone (Maastrichtian to late Campanian?); $14.9 \mathrm{~m}$ of ferruginous clay, claystone, and extremely altered vesicular basalt (Campanian to ?); and $15.8 \mathrm{~m}$ of basalt. The basaltic lava samples appear to be from a single ankaramite flow.

Hole $875 \mathrm{C}$ (outer perimeter ridge), at a water depth of $1408.8 \mathrm{~m}$, penetrated $133.0 \mathrm{mbsf}$ : $0.14 \mathrm{~m}$ of planktonic foraminiferal limestone (late Paleocene through late middle Eocene), $126 \mathrm{~m}$ of grainstone and packstone (middle and late Maastrichtian?, possibly Campanian at base), and $7 \mathrm{~m}$ (126.0-133.0 mbsf) of basalts.

Hole $876 \mathrm{~A}$ (outer perimeter ridge) is located $1.6 \mathrm{~km}$ north-northwest of Site 875. The results of drilling at Site 876 are similar to those at Site 875. Basalts were penetrated in Hole 876 A from 145.5 to 154.0 mbsf $(8.5 \mathrm{~m})$. Holes $875 \mathrm{C}$ and $876 \mathrm{~A}$ ended in relatively thin alkali basalt flows (Premoli Silva, Haggerty, Rack, et al., 1993). They most likely represent a subaerial sequence.

\section{Site 878 (MIT Guyot)}

Massachusetts Institute of Technology (MIT) Guyot (Leg 144, Site 878 ) is an isolated feature close to the Wake Group in the $18^{\circ}-28^{\circ} \mathrm{N}$ guyot band (Premoli Silva, Haggerty, Rack, et al., 1993). Hole 878A is located at a water depth of $1323.2 \mathrm{~m}$ on the south edge of the guyot and ended at 910 mbsf after penetrating $3.2 \mathrm{~m}$ of pelagic sediment (early Pleistocene to latest Albian), $719.34 \mathrm{~m}$ of carbonates and polymictic breccia (late Aptian? to early Aptian), and $187.46 \mathrm{~m}$ of basalt flows and flow-top breccias. Twenty-four flows represent at least three distinct periods of volcanism separated by periods of weathering. The igneous units are hawaiite, basanite, and alkaline olivine basalts.

\section{METHODS}

Basaltic samples from the West Pacific Guyots were analyzed for major elements by standard wet chemistry methods and for minor elements by emission spectral methods and X-ray fluorescence (XRF) analyses. Rare earth elements (REE) were determined by the radiochemical neutron-activation method at the Analytical Center of the Geological Institute, Russian Academy of Sciences. The accuracy of the determination has been checked against USGS BVHO-1 standard (Gladney and Roelandts, 1988). Secondary minerals were studied in thin sections in addition to X-ray diffraction (XRD) in oriented and randomly oriented (bulk powder samples) specimens. The oriented specimens were prepared by kneading 1- to 2-mm-thick sample pieces with distilled water in an agate mortar to produce suspensions of concentrated clay minerals. Each sample was air-dried, treated with glycerine, and heated at $550^{\circ} \mathrm{C}$ for $2 \mathrm{hr}$. ADRON-3 X-ray diffractometer with $\mathrm{CuK} \alpha$ emission, Ni-filter, and slot openings of $0.5,1,1$, and $0.5 \mathrm{~mm}$ was used to analyze the suspension specimens. Igneous rocks were studied in thin sections to determine mineralogy and texture. A few samples were examined by scanning electron microscope (SEM).

\section{PETROGRAPHY}

\section{Allison and Resolution Guyots}

Volcanic rocks of the Allison Guyot are represented by petrographically similar basalts, divided into four units (Sager, Winterer, Firth, et al., 1993). Phyric and microphyric basalts contain different amounts of olivine, pyroxene, and plagioclase phenocrysts, and olivine predominates. Basalts are often incompletely crystallized and vesicular, but massive basalts also occur. Groundmass comprises andesine
$\left(A n_{32-36}\right)$, microlites of pyroxene (Ti-augite), an opaque mineral, and interstitial glass. The texture of the groundmass is intersertal. Alteration is strong to very strong (Tables 1,2). Texture, incomplete crystallization, and vesicularity show that igneous rocks of the Allison Guyot are effusive olivine basalts. The basalts cored on the Allison Guyot are interpreted as shallow sills intruded into soft lagoonal sediments (Sager, Winterer, Firth, et al., 1993).

Igneous rocks of the Resolution Guyot were divided into 12 subunits (Sager, Winterer, Firth, et al., 1993). From the upper part of the sequence (Units 1 to 8 ), we studied olivine-phyric and olivineplagioclase basalts having olivine phenocrysts. The groundmass is represented by laths of plagioclase, microlites of pyroxene, olivine, opaque mineral, and interstitial glass, whereas $\mathrm{K}$-feldspar is found as rare grains. The groundmass texture is intersertal or intergranular. Basalts are massive and vesicular, and basalt alteration is very strong (Tables 1,2).

The lower part of the sequence (Units 10 and 11) is made up of phyric pyroxene-biotite-olivine basalt, which is almost totally crystallized and vesicular. Olivine predominates. The groundmass contains subparallel oriented laths of andesine $\left(\mathrm{An}_{40}\right)$, microlites of augite, opaque mineral, and a small amount of interstitial glass. Basalts display a trachytic texture. Vesicles are about $10 \%-50 \%$ of the rock. Alteration states of basalts are low, moderate, and strong. Volcanic rocks of the Resolution Guyot are represented by olivine basalt. According to shipboard interpretation (Sager, Winterer, Firth, et al., 1993), the basalts represent subaerial flows.

The Allison and Resolution guyots are made up of alkaline olivine basalts of similar composition. Igneous rocks from the lower part of the sequence (Units 10 and 11), recovered on Resolution Guyot, are trachybasalts from an earlier period of the guyot formation.

\section{Lo-En, Wodejebato, and MIT Guyots}

The igneous sequence of the Lo-En Guyot is subdivided into 15 flow units represented by differentiated alkaline olivine basalt, hawaiite, and aphyric or sparsely clinopyroxene-phyric basalts (Premoli Silva, Haggerty, Rack, et al., 1993). We studied two samples from Unit 16. Aphyric basalt (Sample 144-872B-8R-2, 9-12 cm) is incompletely crystallized and vesicular, with pilotaxitic texture, and contains plagioclase laths, clinopyroxene, and opaque mineral microlites. Basalt is brecciated and strongly altered (Table 3). Sample 144-872B-8R-2, 91-94 cm, is biotite-bearing trachybasalt, microphyric, with intergranular texture, vesicular, and moderately altered.

Volcanic rocks of the Wodejebato Guyot are represented in our set of samples by the following: phyric olivine or pyroxene-olivine basalts of ankaramite type and phyric plagioclase-pyroxene-olivine basalts with minor amounts of biotite, moderately to very strongly altered (Hole 874B, Table 3); phyric pyroxene-olivine-plagioclase basalts, moderately altered (Hole $875 \mathrm{C}$, Table 3 ); and sparsely microphyric pyroxene and pyroxene-olivine basalts, strongly altered (Hole 876 A, Table 3).

Basalts of the MIT Guyot in Hole 878A were divided into 35 subunits. The lower 14 units are represented by alkaline olivine basalts. In the upper part of the sequence are basanite, hawaiite, and olivine basalts (Premoli Silva, Haggerty, Rack, et al., 1993). We studied one sample (144-878A-84R-3, 112-115 cm) from Unit 15. The sample is represented by moderately altered phyric pyroxene-olivine basalt.

\section{GEOCHEMISTRY}

Results of bulk chemical analyses are presented in Tables 4, 5, and 6 . We conducted the geochemical research to characterize the primary rock types and to study rock alteration.

\section{Allison and Resolution Guyots}

As shown by shipboard descriptions and confirmed by our results, the volcanic rocks of the Allison and Resolution guyots are undiffer- 
Table 1. Brief petrographic description of analyzed ballasts and secondary minerals, Hole 865A (Allison Guyot).

\begin{tabular}{|c|c|}
\hline $\begin{array}{l}\text { Core, section, } \\
\text { interval }(\mathrm{cm})\end{array}$ & Description \\
\hline $\begin{array}{l}143-865 \mathrm{~A}- \\
90 \mathrm{R}-5,18-21\end{array}$ & $\begin{array}{l}\text { Volcanic breccia tectonized; olivine basalt, euphoric. } \\
\text { Alteration: very strong; olivine phenocrysts, groundmass, and rare pyroxene replaced by smectite and carbonate; carbonate infills thin fissures; opaques partially } \\
\text { replaced by hematite and oxidized. } \\
\text { XRD: smectites both pure and mixed layer with } 10 \%-40 \% \text { mica layers; minor kaolinite; trace hydromica, calcite, hematite, quartz, and } 2.79 \AA \text { mineral (siderite } \\
\text { or phosphate?). }\end{array}$ \\
\hline $90 \mathrm{R}-6,75-77$ & $\begin{array}{l}\text { Pyroxene-plagioclase-olivine basalt phyric, vesicular, incompletely crystallized, with intersertal texture. } \\
\text { Phenocrysts: pyroxene, plagioclase, dominant olivine }(10 \%-15 \%) \text { of rock; glomerophyric aggregates. } \\
\text { Groundmass: subparallel laths of encasing plagioclase }\left(\mathrm{An}_{36}\right) \text {; volcanic glass in interstices, containing opaque dust and dendrite-like, fine-grained aggregates of } \\
\text { magnetite; vesicles (up to } 3 \mathrm{~mm}) \text { make up about } 25 \% \text { of rock. } \\
\text { Alteration: strong; phenocrysts replaced by cryptocrystalline aggregate of smectite and chlorite; outer zone of plagioclase crystals replaced by iddingsite, inner } \\
\text { zone replaced by clay minerals; smectite and chlorite replace groundmass; vesicles infilled with smectite or calcite. } \\
\text { XRD: smectite with interlayer Ca-Mg cations }(13.6-13.9 \mathrm{~A}) \text { and swelling chlorite; trace hydromica, chlorite, kaolinite, calcite, hematite, and gypsum; infilled } \\
\text { vesicular white matter; calcite and trace quartz. }\end{array}$ \\
\hline $91 \mathrm{R}-1,29-32$ & $\begin{array}{l}\text { Olivine-plagioclase basalt, sparsely microphyric, vesicular, with intersertal texture, incompletely crystallized. } \\
\text { Microphenocrysts: plagioclases }(0.2-0.5 \mathrm{~mm}) \text { and rare idiomorphic olivine crystals; microphenocrysts total } 1 \%-3 \% \text { of rock. } \\
\text { Groundmass: plagioclase laths and glass with opaque dust; vesicles }(0.5-3 \mathrm{~mm}) \text { compose about } 10 \% \text { of rock. } \\
\text { Alteration: very strong; olivine replaced by smectite and calcite; plagioclase replaced by smectite; vesicles infilled with smectite; calcite occurs in central part of } \\
\text { vesicles; some vesicles infilled with calcite; calcite replaces pyroxene. } \\
\text { XRD: smectite with interlayer Na-K cations ( } 12.7-13 \AA \text { And with about } 20 \% \text { mica layers; trace kaolinite; trace and minor chlorite, calcite, quartz, K-feldspar, } \\
\text { gypsum, and } 3.51 \AA \text { mineral. }\end{array}$ \\
\hline $92 R-4.45-47$ & $\begin{array}{l}\text { Olivine basalts, sparsely microphyric, with intergranular-microdoleritic texture; euhedral olivine microphenocrysts (as large as } 0.5 \mathrm{~mm} \text { ) compose about } 1 \% \text { of } \\
\text { rock. } \\
\text { Groundmass: unoriented plagioclase laths, small grains of pyroxenes and opaques. } \\
\text { Alteration: very strong; olivine replaced by iddingsite and smectite; plagioclase and pyroxene replaced by smectite; opaque dust partially oxidized; thin fissures } \\
\text { infilled with smectite. } \\
\text { XRD: smectite with interlayer Na-K cations (12.4-12.8 A) and smectite with about } 20 \% \text { mica layers; minor kaolinite; trace hydromica, hematite, gypsum, and K- } \\
\text { feldspar. }\end{array}$ \\
\hline $93 \mathrm{R}-1,35-37$ & $\begin{array}{l}\text { Pyroxene-olivine basalts, phyric, incompletely crystallized, with intersertal texture; euhedral olivine phenocrysts }(0.1-2 \mathrm{~mm}) \text {; central parts of the crystals } \\
\text { replaced by opaque dust; olivine possibly zonal, its central parts being higher in iron; sparsely distributed pyroxene phenocrysts contain opaque dust; } \\
\text { phenocrysts compose about } 20 \% \text { of rock. } \\
\text { Groundmass: unoriented plagioclase laths, pyroxene microlites, opaque mineral, and interstitial glass. } \\
\text { Alteration: very strong; olivine and pyroxene completely replaced by iddingsite and smectite: plagioclase and groundmass glass replaced by smectite. } \\
\text { XRD: smectite with interlayer Na-K cations }(12.8 \AA) \text { and with about } 30 \% \text { mica layers; minor kaolinite, calcite, and hematite; trace hydromica, chlorite, gypsum, } \\
\text { and K-feldspar; } 2.70 \AA \text { mineral unidentified. }\end{array}$ \\
\hline $93 R-3,47-49$ & $\begin{array}{l}\text { Pyroxene-olivine basalt, phyric, slightly vesicular, almost totally crystallized, with intersertal texture. } \\
\text { Phenocrysts: euhedral zonal olivine }(0.3-1.5 \mathrm{~mm}) \text {; sparsely prismatic zonal olivine crystals; phenocrysts total about } 20 \% \text { of rock. } \\
\text { Groundmass: unoriented plagioclase laths (andesine, An } \mathrm{An}_{32} \text { ); small grains of Ti-augite, olivine, opaque mineral, and glass; rare vesicles (up to } 2 \mathrm{~mm} \text { ). } \\
\text { Alteration: strong; olivine and pyroxene zonally replaced; outer zone replaced by iddingsite, central part replaced by chlorite; Ti-augite and groundmass glass } \\
\text { replaced by chlorite; vesicles infilled with clay mineral. }\end{array}$ \\
\hline $94 \mathrm{R}-2,103-104$ & $\begin{array}{l}\text { Olivine basalt, phyric, vesicular, almost totally crystallized, with pilotaxitic texture. } \\
\text { Phenocrysts: euhedral and subhedral olivine crystals (up to } 1 \mathrm{~mm} \text { ); phenocrysts total about } 10 \%-15 \% \text { of rock. } \\
\text { Groundmass: subparallel oriented plagioclase laths, small grains of pyroxene, interstitial glass and opaque dust; vesicles (to } 3 \mathrm{~mm} \text { ) compose about } 20 \% \text { of rock. } \\
\text { Alteration: very strong; olivine completely replaced by smectite, chlorite, iddingsite, and calcite; plagioclases partially replaced by chlorite/smectite; groundmass } \\
\text { glass replaced by smectite/chlorite; vesicles infilled with chlorite and calcite, } \\
\text { XRD: swelling chlorite; mixed layer smectite-chlorite mineral; minor hematite; trace hydromica, chlorite, kaolinite, and gypsum; vesicles infilled with smectite } \\
\text { containing about } 20 \% \text { mica layer; trace serpentine. }\end{array}$ \\
\hline
\end{tabular}

entiated alkaline olivine basalts and trachybasalts (Sager, Winterer, Firth, et al., 1993). Chemical composition of the basalts was transformed by strong alteration, mainly for $\mathrm{Fe}, \mathrm{Al}$, and $\mathrm{Mg}$. Altered chemical composition impedes correct geochemical analysis. Nevertheless, the results show that basalts of both guyots are represented by $\mathrm{K}-\mathrm{Na}$ alkaline basalts and in some cases by potassium basalts (Tables 4,5 ). This is in good agreement with a more extensive geochemical study by Baker et al. (1995).

In MacDonald's variation diagram (Fig. 1), basalts of the Allison and Resolution guyots are located in the field of alkaline volcanic rocks with a weakly expressed Hawaiian trend of differentiation. On the AFM diagram (Fig. 2), samples from the Allison and Resolution guyots are in the intraplate alkaline field with a ferruginous (Iceland) trend of differentiation. This may be a result of the strong alteration of the basalts.

The variation diagram in Figure 3 shows the main rock-forming elements $\left(\mathrm{CaO}, \mathrm{FeO}^{*}, \mathrm{MgO}, \mathrm{K}_{2} \mathrm{O}, \mathrm{TiO}_{2}, \mathrm{Al}_{2} \mathrm{O}_{3}\right)$ and minor elements $(\mathrm{V}$, $\mathrm{Ni}, \mathrm{Cr}$ ) vs. the differentiation index $\mathrm{MG}\left(\mathrm{Mg} / \mathrm{Mg}+\mathrm{Fe}^{2+}\right)$. As shown, correlation between these parameters is absent, indicating that the chemical composition of the basalts was strongly affected by alteration.

Trends of the REE distribution in alkaline basalts and trachybasalts of the Allison and the Resolution guyots are the same. $\mathrm{La}, \mathrm{Ce}$, and Nd increase somewhat in basalts of the Allison Guyot (Figs. 4,5). Concentration of the REE in basalts of both guyots is similar to those in alkaline basalts of the Hawaiian Islands. Geochemical results show that volcanic rocks of the Allison and Resolution guyots are similar and belong to the intraplate alkaline $\mathrm{K}-\mathrm{Na}$ basalts.

\section{Lo-En, Wodejebato, and MIT Guyots}

The geochemical data show that the volcanic rocks of the Lo-En, Wodejebato, and MIT guyots represented in our samples are weakly differentiated alkaline olivine basalts with trachytic and basanite trends of differentiation. Chemical composition of the igneous rocks is transformed by alteration (Table 6).

On the MacDonald's variation diagram (Fig. 6), the volcanic rocks of these guyots fall into the group of silica-undersaturated, weakly differentiated, alkaline olivine basalts with basanite trend of differentiation according to alkaline elements. Alkaline olivine basalts and ankaramites from the Wodejebato Guyot are more differentiated. The AFM diagram (Fig. 7) demonstrates the same features.

Variation diagrams on Figure 8 show a correlation between $\mathrm{MgO}$, $\mathrm{Cr}, \mathrm{Ni}, \mathrm{Al}_{2} \mathrm{O}_{3}$, and $\mathrm{K}_{2} \mathrm{O}$. As shown on the diagrams, basalts from the Wodejebato Guyot are more differentiated. REE distribution in basalts (Fig. 9) suggests that the volcanic rocks are derived from a deep intraplate magma source. The basanite of the MIT Guyot is relatively enriched in REE. The olivine basalts and ankaramites of the Wodejebato Guyot are more differentiated. 
Table 2. Brief petrographic description of analyzed basalts and secondary minerals, Hole 866A (Resolution Guyot).

Core, section,
interval $(\mathrm{cm})$

$143-866 \mathrm{~A}$ -

171R-2, 109-111 Olivine basalt, phyric, primary texture of groundmass unidentifiable.

Phenocrysts: olivine $(0.1-1 \mathrm{~mm})$ about $15 \%$ of rock.

Groundmass: unoriented plagioclase laths, microlites of olivine $(0.03-0.1 \mathrm{~mm})$, and opaque mineral; rare unhedral K-feldspar replacing plagioclase.

Alteration: very strong; olivine and groundmass completely replaced by smectite.

XRD: kaolinite and heterogeneous smectites; smectites contain about $30 \%-40 \%$ mica layers; minor hematite; trace $\mathrm{K}$-feldspar.

171R-3, 121-123 Olivine basalt, phyric, weakly vesicular, incompletely crystallized, with intersertal texture.

Phenocrysts: euhedral olivine phenocrysts $(0.2-1 \mathrm{~mm})$ compose up to $15 \%$ of rock.

Groundmass: represented by unoriented plagioclase laths, small grains of pyroxene, opaque mineral, and interstitial glass.

Alteration: very strong; olivine completely replaced by smectite, chlorite, and carbonate; groundmass replaced by smectite; vesicles ( $0.5-1$ mm) infilled with smectite and/or carbonate.

XRD: smectites with interlayer Na-K cations (12.6 $\AA$ ); minor kaolinite; trace chlorite, calcite, hematite, and gypsum; white matter = unfilled large vesicular calcite, ankerite, and quartz (latter as trace).

178W-1, 37-39 Plagioclase-olivine basalt, phyric, weakly crystallized, hyalopilitic texture,

Phenocrysts: represented mainly by euhedral olivine crystals $(0.3-1 \mathrm{~mm})$ and rare plagioclase phenocrysts; phenocrysts total about $10 \%$ of rock.

Groundmass: represented by plagioclase microlites, volcanic glass, and opaque dust; tectonized rock.

Alteration: very strong: smectitized and carbonatized olivine and plagioclase phenocrysts; groundmass, including glass, replaced by smectite, carbonate, and hematite; thin fissures infilled with smectite and carbonate.

XRD: smectite with interlayer Na-K cations $(12.3 \AA)$; minor kaolinite and hematite; trace hydromica.

178W-1, 79-81 Aphyric apobasalt completely replaced by smectite and oxidized opaque matter.

Alteration: very strong.
XRD: smectite with interlayer Na-K cations $(12.1 \AA)$ and with about $10 \%$ mica layers; minor kaolinite; trace quartz and $3.51 \AA$ mineral.

$182 \mathrm{R}-4,38-40 \quad$ Olivine basalt, microphyric, vesicular, incompletely crystallized, with pilotaxitic texture.

Microphenocrysts: olivine (up to $0.5 \mathrm{~mm}$ ) composes about $10 \%$ of rock.

Groundmass: represented by unoriented and subparallel oriented plagioclase laths, small grains of pyroxene, interstitial glass, and opaque dust; vesicles (up to 3 $\mathrm{mm}$ ) total about $20 \%$ of rock.

Alteration: very strong; olivine completely replaced by smectite; outer part replaced by oxidized Fe; plagioclase replaced by smectite and hematite; interstitial

XRD; smectite with interlayer Na-K cations $(12.4 \AA)$ and with about $10 \%$ mica layers; trace hematite and $\mathrm{K}$-feldspar.

182R-4, 72-74 Olivine basalt, sparsely microporphyritic, vesicular, intergranular texture.

Microphenocrysts: idiomorphic olivine (up to $0.5 \mathrm{~mm}$ ) composes about $5 \%$ of rock.

Groundmass: represented by unoriented plagioclase laths, pyroxene microlites, opaque dust, and interstitial glass.

Alteration: moderate; olivine and pyroxene replaced by smectite and iddingsite; plagioclase replaced by smectite and opaque dust; glass replaced by smectite; vesicles infilled and encrusted with smectite, some with oxidized $\mathrm{Fe}$.

XRD: smectite with interlayer $\mathrm{Na}-\mathrm{K}$ cations $(12.4 \AA)$ and with about $10 \%$ mica layers; trace hematite and $4.87 \AA$ mineral.

184R-1,27-28 Pyroxene-biotite-olivine trachybasalt, microdoleritic, with trachytic texture.

Microphenocrysts: represented by euhedral olivine crystals, biotite, and pyroxene; phenocrysts total about $15 \%$ of rock: biotite and olivine dominate.

Groundmass: represented by subparallel oriented plagioclase ( $\left(\right.$ andesine, $\mathrm{An}_{40}$ ) laths, augite microlites, opaque mineral, and a very small amount of interstitial glass; presence of rare vesicles.

Alteration: low; olivine replaced by iddingsite; pyroxene replaced by smectite; plagioclase sericitized; groundmass glass smectitized; thin fissures and vesicles infilled with smectite.

XRD: smectite with interlayer Na-K cations $(13 \AA$ ) and about $10 \%$ mica layers; trace kaolinite and quartz; thin fissure infilled by smectite with interlayer $\mathrm{Na}-\mathrm{K}$ cations $(12.7 \AA)$.

184R-1, 137-139 Microphyric, vesicular pyroxene-olivine basalt incompletely crystallized, with intersertal (some parts with hyalopilitic) texture; brecciated rock.

Microphenocrysts: represented mainly by euhedral olivine crystals $(0.1-0.3 \mathrm{~mm})$ and sparsely prismatic crystals of pyroxene; phenocrysts total about $7 \%-10 \%$ of rock.

Groundmass: represented by unoriented plagioclase laths, pyroxene microlites, opaque dust, and interstitial glass; vesicles (1.5-2 mm) compose about $20 \%$ of rock.

Alteration: moderate; olivine and pyroxene phenocrysts replaced by iddingsite and smectite; plagioclase replaced by smectite; glass replaced by smectite and contains opaque dust; vesicles infilled with smectite.

XRD: smectite with different interlayer cations: $\mathrm{Na}-\mathrm{K}(12.8 \AA)$ and $\mathrm{Ca}-\mathrm{Mg}(14.7 \AA)$; trace hematite and quartz.

184R-2, 23-26 Olivine trachybasalt, phyric, vesicular, with trachytic texture; hypidiomorphic olivine crystals (1.5-2 mm) total about $7 \%-10 \%$ of rock.

Microphenocrysts: sparsely prismatic pyroxene.

Groundmass: subparallel oriented plagioclase laths, microlites of pyroxene, and opaque dust; vesicles compose about $10 \%$ of rock.

Alteration: strong; olivine and pyroxene completely replaced by iddingsite and smectite; plagioclase replaced by smectite; vesicles encrusted with smectite with oxidized $\mathrm{Fe}$.

XRD: smectite with interlayer $\mathrm{Na}-\mathrm{K}$ cations $(12.5 \AA)$; minor hematite.

186R-1, 39-41 Biotite-olivine trachybasalt, microphyric, strongly vesicular, with trachytic texture.

Phenocrysts: represented by euhedral olivine crystals $(0.1-0.3$ to $1.5-2 \mathrm{~mm})$; biotite size $=0.1-0.2 \mathrm{~mm}$.

Groundmass: subparallel oriented plagioclase laths, microlites of pyroxene, and euhedral grains of opaque mineral; vesicles (4-5 mm) compose about $50 \%$ of rock.

Alteration: strong; olivine replaced by smectite; small crystals replaced by iddingsite; plagioclase replaced by smectite; iddingsitized pyroxene and biotite; smectitized and oxidized glass; vesicles infilled with smectite.

XRD: smectite with interlayer $\mathrm{Ca}-\mathrm{Mg}$ cations $(14.9 \AA)$; trace hematite and gypsum; gray-blue matter from vesicles = smectite with interlayer Ca-Mg cations $(14.7 \AA)$.

\section{ALTERATION}

\section{Allison Guyot (Hole 865A)}

Thin sections and XRD data of clay fractions extracted from basalts and bulk samples show that the rocks are strongly to very strongly altered (Table 1). According to chemical analyses, the altered basalts contain $3.8-7.2 \mathrm{wt} \% \mathrm{H}_{2} \mathrm{O}^{+}$(Table 4).
The altered basalts are characterized by a high concentration of swelling clay minerals, including smectite and/or swelling chlorite and mixed-layer minerals. These minerals replace olivine, groundmass glass, plagioclase, and pyroxene (Table 1). Often the primary minerals are totally replaced by the alteration products, occurring as pseudomorphs. The smectite group comprises both pure smectite and mixed-layer minerals, with $10 \%-40 \%$ mica layers and different predominating interlayer cations ( $\mathrm{Na}-\mathrm{K}$ or $\mathrm{Ca}-\mathrm{Mg}$ ). Other clay minerals 
Table 3. Brief petrographic descriptions of analyzed basalts and secondary minerals, Hole 872B (Lo-En Guyot), Holes 874B, 875C, and 876A (Wodejebato Guyot), and Hole 878A (MIT Guyot).

\footnotetext{
Core, section,

interval $(\mathrm{cm})$

Description

144-872B-

8R-2, 9-12 Brecciated basalt, aphyric, incompletely crystallized, vesicular, with pilotaxitic texture.

Groundmass: represented by laths of plagioclase, microlites of clinopyroxene and opaque mineral; vesicles (up to $2 \mathrm{~mm}$ ) make up about $20 \%$ of rock.

Alteration: very strong; plagioclase, clinopyroxene, and groundmass glass replaced by smectite and carbonate; vesicles and thin fissures infilled with smectite, carbonate, and zeolite.

XRD: smectite with interlayer Ca-Mg cations (14.8 $\AA$ ) and about $20 \%$ mica layer, calcite, and chabazite.

8R-2, 91-94 Biotite trahybasalt microphyric, vesicular, with intergranular texture (some parts with trahytic-like); microphenocrysts of biotite (up to 0.3 mm) compose 5\%$7 \%$ of rock.

Groundmass: represented by subparallel oriented and inoriented plagioclase laths, clinopyroxene microlites, and opaque mineral; vesicles ( $0.5-1$ mm) make up about $15 \%-20 \%$ of rock.

Alteration: moderate.

XRD: smectite with interlayer Ca-Mg cations $(14.8 \AA)$ and calcite.
}

144-874B-

24R-1, 108-110 Olivine basalt (ankaramite), massive, phyric, with pilotaxitic texture

Phenocrysts: olivine (up to 3-4 mm) composes about $50 \%$ of rock; olivines of two types: very strongly replaced with smectite-chlorite aggregates, carbonate, and oxidized opaque mineral, and fresh.

Groundmass: represented by microlites of plagioclase, clinopyroxene, and opaque mineral.

Alteration: very strong; smectite-chlorite aggregates almost completely replace groundmass and olivine phenocrysts.

XRD: smectite with interlayer $\mathrm{Ca}-\mathrm{Mg}$ cations $(14.6 \AA)$; minor mixed layer smectite-chlorite and calcite; trace chlorite.

24R-1,115-118 Pyroxene-olivine phyric basalt (ankaramite), primary texture of groundmass cannot be identified.

Phenocrysts: olivine (up to $3-4 \mathrm{~mm}$ ) about $50 \%$ of rock, and Ca-augite.

Groundmass: composes much of opaque mineral.

Alteration: very strong; olivine and groundmass completely replaced by smectite-chlorite aggregate; carbonate replaces $\mathrm{Ca}$-augite.

XRD: smectite with interlayer Ca-Mg cations $(15.1 \mathrm{~A})$, mixed-layer smectite-chlorite, serpentine, and calcite.

24R-2, 74-77 Pyroxene-olivine basalt (ankaramite) phyric, with microlitic texture.

Phenocrysts: olivine (up to $2-5 \mathrm{~mm}$ ) makes up about $50 \%$ of rock, and augite.

Groundmass: represented by laths of plagioclase, microlites of clinopyroxene, and opaque mineral.

Alteration: strong; olivine completely replaced by smectite-chlorite aggregate and by oxidized opaque mineral; fresh augite; groundmass pyroxene and particularly plagioclase replaced by smectite and chlorite; microfissures infilled with smectite-chlorite aggregate.

XRD: trace smectite, mixed-layer smectite-chlorite minerals, calcite, serpentine, and quartz.

24R-4, 54-72 Biotite-plagioclase-pyroxene-olivine basalt, with microlitic texture.

Phenocrysts: dominant olivine; clinopyroxene, plagioclase (andesine- $\mathrm{An}_{47}$ and labradorite- $\mathrm{An}_{52}$ ), and biotite; phenocrysts compose about $50 \%$ of rock.

Groundmass: represented by laths of plagioclase (andesine- $\mathrm{An}_{38}$ ), microlites of augite, and opaque mineral.

Alteration: moderate; olivine and biotite completely replaced by smectite and chlorite; olivine often replaced by carbonate and oxidized Fe; plagioclase and clinopyroxene mainly fresh; groundmass minerals replaced by smectite and chlorite.

XRD: smectite; minor chlorite and mixed layer smectite-chlorite; smectite with trace chlorite and hydromica; vesicle infilled with calcite; microfissures infilled by smectite with about $20 \%$ interlayers of mica type.

$144-875 \mathrm{C}-$

$15 \mathrm{M}-1,35-37$

Pyroxene-olivine-plagioclase basalt, phyric, vesicular, with intergranular texture (same parts with microophitic).

Phenocrysts $(0.3-2 \mathrm{~mm})$ : compose about $15 \%-20 \%$ of rock and represented by dominant plagioclase (andesine- $\mathrm{An}_{48}$ ), olivine, and pyroxene.

Groundmass: represented by laths of plagioclase, and microlites of Ti-augite and opaque mineral; vesicles (up to $2-3 \mathrm{~mm}$ ) make up about $10 \%$ of rock.

Alteration: moderate; smectite-chlorite aggregates completely replace phenocrysts of olivine and pyroxene, partially replace groundmass, and infill vesicles.

XRD: smectite with interlayer Ca-Mg cations (14.6 $\AA$ ); mixed-layer smectite-chlorite; trace chlorite and hydromica.

$144-876 \mathrm{~A}-$

15R-1, 32-34 Pyroxene-olivine basalt, sparsely microphyric, incompletely crystallized, vesicular, with pilotaxitic texture.

Microphenocrysts $(0.1-0.3 \mathrm{~mm})$ : make up about $1 \%$ of rock and represented by olivine and olivine-augite aggregate.

Groundmass: represented by subparallel oriented laths of plagioclase, and microlites of olivine and opaque mineral; presence of idiomorphic quench-crystals; vesicles (up to $3-5 \mathrm{~mm}$ ) make up about $10 \%$ of rock.

Alteration: very strong; interstitial glass and microlites of plagioclase replaced by smectite-chlorite aggregate; olivine replaced by smectite and oxidized vesicles and microfissures infilled with zeolite.

XRD: smectite with about $20 \%$ mica layers and mixed-layer smectite-chlorite minerals; trace chlorite and hydromica; calcite and chabazite in fissures; smectite with about $30 \%-40 \%$ mica layers; vesicles infilled with trace hydromica and chlorite.

16R-1, 6-8 Pyroxene basalt, sparsely microphyric, vesicular, with microlitic texture (some parts with trachytic-like texture); microphenocrysts of clinopyroxene, oxidized olivine, and plagioclase make up about $1 \%$ of rock.

Groundmass: represented by unoriented (some parts with subparallel oriented) microlites and laths of plagioclase (andesine- $\left.\mathrm{An}_{42}\right)$, microlites of augite, and opaque mineral; vesicles compose about $5 \%-10 \%$ of rock.

Alteration: strong; groundmass and microphenocrysts replaced by smectite; vesicles infilled with smectite; microfissures infilled with carbonate.

XRD: smectite with interlayer Ca-Mg cations $(14-14.4 \AA)$ and about $20 \%$ mica layers; trace mixed layer smectite-chlorite mineral and hydromica; microfissures infilled with calcite and trace quartz.

$144-878 \mathrm{~A}$

84R-3,112-115 Pyroxene-olivine basalt, phyric, vesicular, with microphytic texture.

Phenocrysts $(0.2-1.5 \mathrm{~mm})$ : make up about $25 \%$ of rock and represented by dominant olivine $(90 \%-95 \%)$.

Groundmass: represented by weakly subparallel oriented laths of plagioclase (labradorite- $\mathrm{An}_{52}$ ), aggregates of small crystals of $\mathrm{Ti}$-augite and opaque mineral (Ti-magnetite).

Alteration: moderate; olivine and groundmass by smectite; vesicles infilled with smectite.

XRD: smectite with interlayer $\mathrm{Ca}-\mathrm{Mg}$ cations $(15.3 \AA)$; trace hydromica, mixed-layer smectite-chlorite, and chlorite; microfissures infilled with smectite and trace chlorite.

identified include Na-hydromica, chlorite, kaolinite, and serpentine (Table 1), which commonly occur either as traces or minor constituents. The SEM photographs show interstitial glass replaced by smectite and plagioclase, with kaolinite in cavities (Plate 1, Figs. 1-3) and smectites infilling vesicles (Plate 2, Figs. 1,2).

Non-clay alteration products are calcite, hematite, quartz, gypsum, $2.79 \AA$-mineral (siderite or phosphate?), and 3.51 $\AA$-mineral (unidenti- fied). Calcite is often formed in central parts of olivine phenocrysts and infills pores together with smectite and traces of quartz. Hematite and swelling clay minerals replace olivine. The distribution of secondary minerals and their chemical data are shown on Figure 10.

At the top of Unit 1 (Samples 143-865A-90R-4, 93-94 cm, and $-90 \mathrm{R}-5,18-21 \mathrm{~cm}$ ), smectites having predominately $\mathrm{Na}-\mathrm{K}$ cations in interlayers are the main secondary minerals. Both pure smectites and 
Table 4. Chemical analyses of basalts from Hole 865A (Allison Guyot).

\begin{tabular}{|c|c|c|c|c|c|c|c|c|c|c|c|c|}
\hline & \multicolumn{2}{|c|}{1} & \multicolumn{2}{|c|}{2} & \multicolumn{2}{|c|}{3} & \multicolumn{2}{|c|}{4} & \multicolumn{2}{|c|}{5} & \multicolumn{2}{|c|}{6} \\
\hline & a & $\mathrm{b}$ & a & $\mathrm{b}$ & a & $\mathrm{b}$ & a & b & a & b & a & b \\
\hline \multicolumn{13}{|c|}{ Major element (wt\%): } \\
\hline $\mathrm{SiO}_{2}$ & 41.80 & 49.37 & 41.22 & 45.58 & 41.00 & 47.16 & 41.00 & 46.18 & 40.19 & 43.40 & 39.97 & 46.17 \\
\hline $\mathrm{TiO}_{2}^{2}$ & 4.69 & 5.54 & 2.97 & 3.28 & 4.85 & 5.58 & 4.42 & 4.98 & 4.26 & 4.60 & 4.27 & 4.93 \\
\hline $\mathrm{Al}_{2} \mathrm{O}_{3}$ & 22.71 & 26.82 & 16.40 & 18.13 & 22.32 & 25.68 & 19.19 & 21.62 & 15.09 & 16.29 & 17.41 & 20.11 \\
\hline $\mathrm{Fe}_{2} \mathrm{O}_{3}$ & 5.71 & 6.74 & 8.06 & 8.91 & 10.50 & 12.08 & 12.06 & 13.58 & 7.05 & 7.61 & 6.12 & 7.07 \\
\hline $\mathrm{FeO}$ & 1.14 & 1.35 & 2.96 & 3.27 & 1.10 & 1.27 & 1.66 & 1.87 & 4.20 & 4.54 & 2.46 & 2.84 \\
\hline $\mathrm{MnO}$ & 0.01 & 0.01 & 0.11 & 0.12 & 0.05 & 0.06 & 0.12 & 0.14 & 0.21 & 0.23 & 0.01 & 0.01 \\
\hline $\mathrm{MgO}$ & 2.75 & 3.25 & 7.91 & 8.75 & 1.61 & 1.85 & 2.17 & 2.44 & 10.46 & 11.29 & 8.27 & 9.55 \\
\hline $\mathrm{CaO}$ & 2.63 & 3.11 & 5.84 & 6.46 & 1.55 & 1.78 & 2.75 & 3.10 & 7.41 & 8.00 & 3.24 & 3.74 \\
\hline $\mathrm{Na}_{2} \mathrm{O}$ & 1.40 & 1.65 & 1.89 & 2.09 & 1.35 & 1.55 & 1.73 & 1.95 & 2.05 & 2.21 & 1.09 & 1.26 \\
\hline $\mathrm{K}_{2} \mathrm{O}$ & $\begin{array}{l}1.60 \\
1.63\end{array}$ & 1.93 & 2.95 & 3.26 & 2.51 & 2.89 & 3.28 & $\begin{array}{l}3.69 \\
\end{array}$ & 1.47 & 1.59 & 3.62 & 4.18 \\
\hline $\mathrm{P}_{2} \mathrm{O}_{5}$ & 0.20 & 0.24 & 0.13 & 0.14 & 0.09 & 0.10 & 0.40 & 0.45 & 0.22 & 0.24 & 0.11 & 0.13 \\
\hline $\mathrm{H}_{2} \mathrm{O}^{-}$ & 6.53 & & 3.05 & & 5.95 & & 4.80 & & 2.31 & & 5.28 & \\
\hline $\mathrm{H}_{2}^{2} \mathrm{O}^{+}$ & 7.21 & & 3.84 & & 6.12 & & 5.02 & & 4.62 & & 6.28 & \\
\hline $\mathrm{CO}_{2}$ & & & & & & & & & & & 0.60 & \\
\hline LOI & 0.96 & & 2.19 & & 0.87 & & 0.81 & & 0.51 & & 1.04 & \\
\hline Total & 99.49 & 100.00 & 99.52 & 100.00 & 99.87 & 100.00 & 99.41 & 100.00 & 100.05 & 100.00 & 99.74 & 100.00 \\
\hline \multicolumn{13}{|c|}{ Trace element (ppm): } \\
\hline & 515 & & 385 & & 210 & & 370 & & 300 & & 355 & \\
\hline $\mathrm{Ni}$ & 300 & & 400 & & 150 & & 220 & & 270 & & 155 & \\
\hline $\mathrm{v}$ & 620 & & 350 & & 330 & & 290 & & 325 & & 370 & \\
\hline $\mathrm{La}$ & 64 & & 39 & & 63 & & 54 & & 42 & & 35 & \\
\hline $\mathrm{Ce}$ & 150 & & 88 & & 130 & & 120 & & 98 & & 96 & \\
\hline $\mathrm{Nd}$ & 72 & & 36 & & 63 & & 54 & & 42 & & 48 & \\
\hline Sm & 14 & & 7.2 & & 11 & & 10 & & 8.5 & & 9.3 & \\
\hline $\mathrm{Eu}$ & 4.6 & & 2.3 & & 3.4 & & 3.3 & & 2.8 & & 2.8 & \\
\hline $\mathrm{Tb}$ & 2.3 & & 0.90 & & 1.3 & & 1.3 & & 1.1 & & 1.2 & \\
\hline $\mathrm{Yb}$ & 2.9 & & 1.7 & & 1.6 & & 2.4 & & 1.9 & & 1.9 & \\
\hline Lu & 0.43 & & 0.24 & & 0.20 & & 0.35 & & 0.26 & & 0.26 & \\
\hline
\end{tabular}

Notes: Column a represents the real chemical composition, and column b represents the chemical composition recalculated for $100 \%$. Samples are as follows: $1=143-865 \mathrm{~A}-90 \mathrm{R}-4$. $93-94 \mathrm{~cm} ; 2=143-865$ A-90R-6, 75-77 cm; $3=143-865 \mathrm{~A}-92 \mathrm{R}-4,45-47 \mathrm{~cm} ; 4=143-865 \mathrm{~A}-93 \mathrm{R}-1,35-37 \mathrm{~cm} ; 5=143-865 \mathrm{~A}-93 \mathrm{R}-3,47-49 \mathrm{~cm} ;$ and $6=143-865 \mathrm{~A}-94 \mathrm{R}-2,103-$ $104 \mathrm{~cm}$.

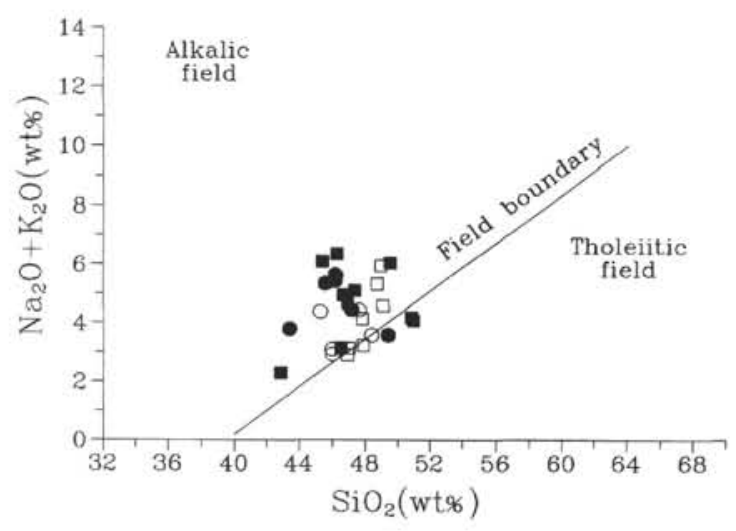

Figure 1. MacDonald's (1968) variation diagram of basalts from Holes 865A (Allison Guyot) and 866A (Resolution Guyot). Solid circles = Hole 865A, new data on basalts; solid squares $=$ Hole $866 \mathrm{~A}$, new data on basalts; open circles $=$ Hole 865A, basalts (Sager, Winterer, Firth, et al., 1993); and open squares = Hole 866A, basalts (Sager et al., 1993).

those with mica layers $(10 \%-40 \%)$ are common. Kaolinite and calcite are identified. Traces of hydromica, gypsum, hematite and phosphate (?) were also identified by XRD. Basalts in the upper part of the unit are very strongly altered $\left(\mathrm{H}_{2} \mathrm{O}^{+}=7.2 \mathrm{wt} \%\right)$, oxidized $\left(\mathrm{Fe}_{2} \mathrm{O}_{3} /\left[\mathrm{Fe}_{2} \mathrm{O}_{3}+\right.\right.$ $\mathrm{FeO}]=0.85$ ) and leached in silica, probably caused by subaerial weathering $\left(\mathrm{Al}_{2} \mathrm{O}_{3} / \mathrm{SiO}_{2}=0.54\right)$. Just below the top (Sample 143$865 \mathrm{~A}-90 \mathrm{R}-6,75-77 \mathrm{~cm}$ ), smectite with $\mathrm{Ca}-\mathrm{Mg}$ cations interlayered and swelling chlorite are the predominant minerals, whereas hydromica, chlorite, kaolinite, calcite, hematite, and gypsum occur as traces. The chemical data demonstrate lower water content $\left(\mathrm{H}_{2} \mathrm{O}^{+}\right.$less than about $4 \mathrm{wt} \%$ ), and higher magnesium ( $\mathrm{MgO}$ up to $8 \mathrm{wt} \%, \mathrm{MgO} /[\mathrm{MgO}$ $\left.+\mathrm{Fe}_{2} \mathrm{O}_{3}+\mathrm{FeO}\right]$ ratio up to 0.4 ), thus indicating a decrease in weathering downward from the surface. However, a sample from the central part of the unit (Sample 143-865A-91R-1, 23-32 cm) also shows mineral composition similar to that at the top.

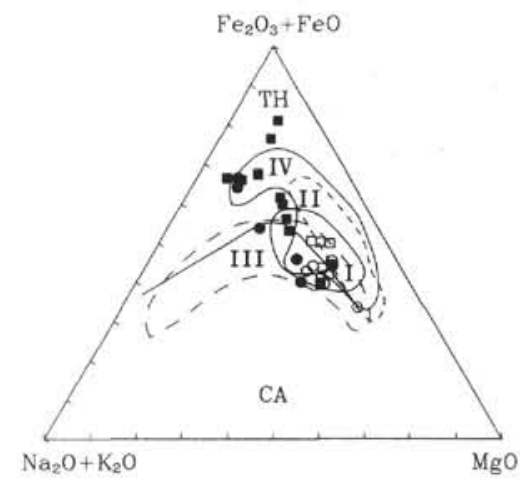

Figure 2. AFM diagram of basalts from Hole 865A (Allison Guyot) and Hole 866A (Resolution Guyot). I = field of Discovery Rise and Walvis Ridge; $\mathrm{II}=$ MORB field; III = field of subalkaline and alkaline basalts of Hawaii, Cocos, and Cape Verde islands; and IV = field of Iceland basalts. Symbols are the same as in Figure 1.

Unit 3 was more completely sampled. Three samples from the upper $6 \mathrm{~m}$ of the unit show downward-changing trends similar to those found in Unit 1 . However, the strongly altered (weathered) zone at the top is thicker here (Samples 143-865A-92R-4, 45-47 cm, and 143-865A-93R-1, 35-37 cm). The central zone (Sample 143-865A$93 \mathrm{R}-3,47-49 \mathrm{~cm}$ ) with predominately swelling chlorite and mixedlayer smectite-chlorite is well expressed, showing $\mathrm{MgO}$ content up to $8 \mathrm{wt} \%$ and $\mathrm{MgO} /\left(\mathrm{MgO}+\mathrm{Fe}_{2} \mathrm{O}_{3}+\mathrm{FeO}\right)$ ratios up to 0.5 . In a sample from the bottom of Unit 3 (Sample 143-865A-94R-2, 103-104 cm), kaolinite is absent and trace amounts of serpentine were detected. The upper part of Unit 4 (Sample 143-865A-94R-4, 46-47 cm) demonstrated alteration products dominated by smectite with $\mathrm{Ca}-\mathrm{Mg}$ cations in interlayer position, whereas kaolinite was not found by XRD.

In all basalt samples from Hole $865 \mathrm{~A}$, vesicles and thin fissures are infilled either by smectite with dominant $\mathrm{Na}$ and $\mathrm{K}$ as interlayer 

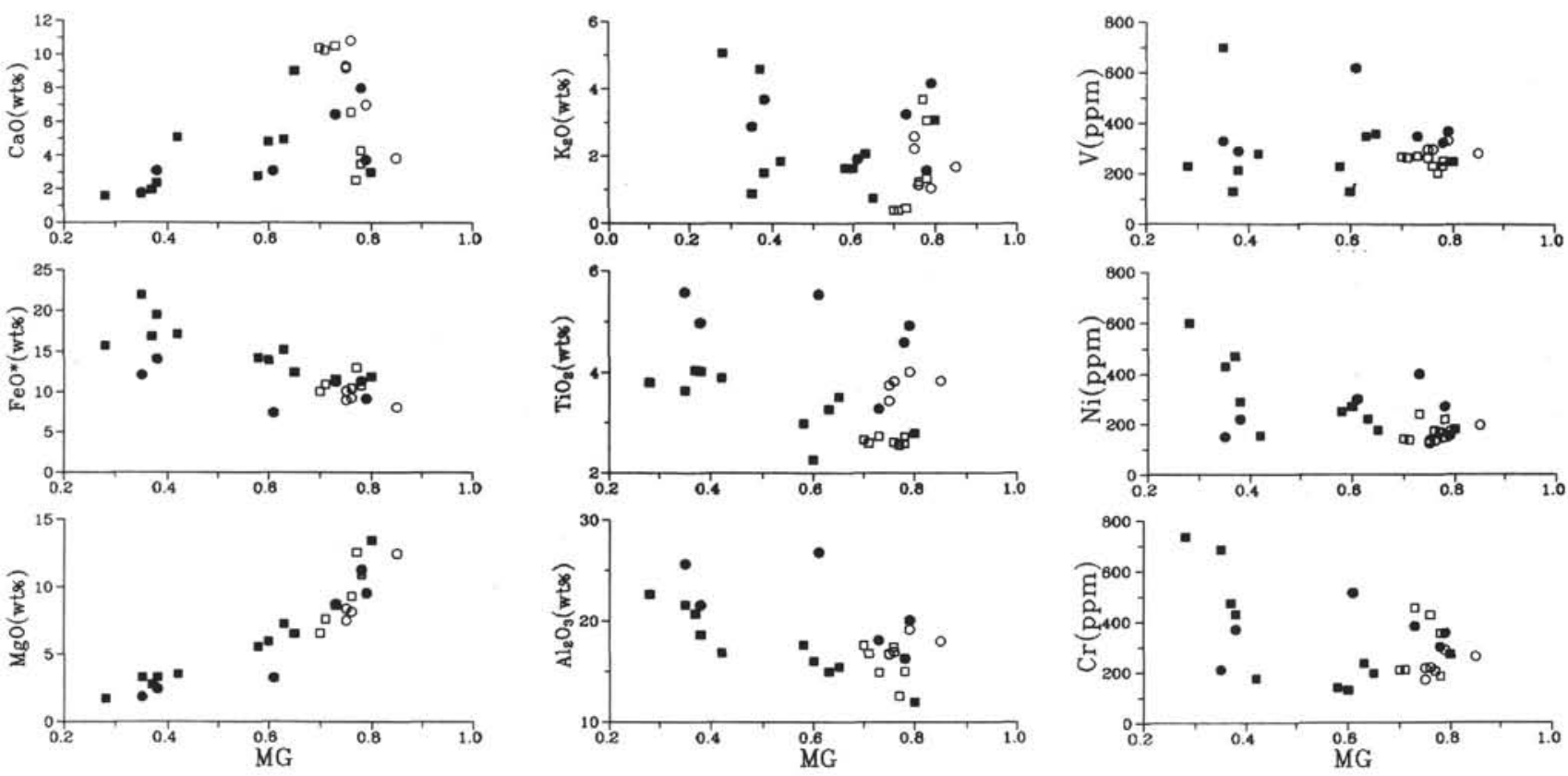

Figure 3. Variation diagrams for major and minor elements vs. $\mathrm{MG}=\mathrm{Mg} /\left(\mathrm{Mg}+\mathrm{Fe}^{2+}\right)$ of basalts from Holes $865 \mathrm{~A}$ (Allison Guyot) and $866 \mathrm{~A}$ (Resolution Guyot). Symbols are the same as in Figure 1.

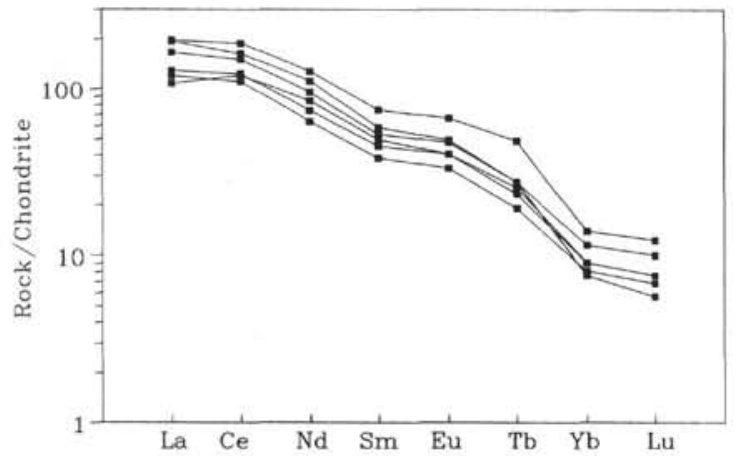

Figure 4. Rare earth elements in basalts from Hole 865A (Allison Guyot), normalized to chondrite.

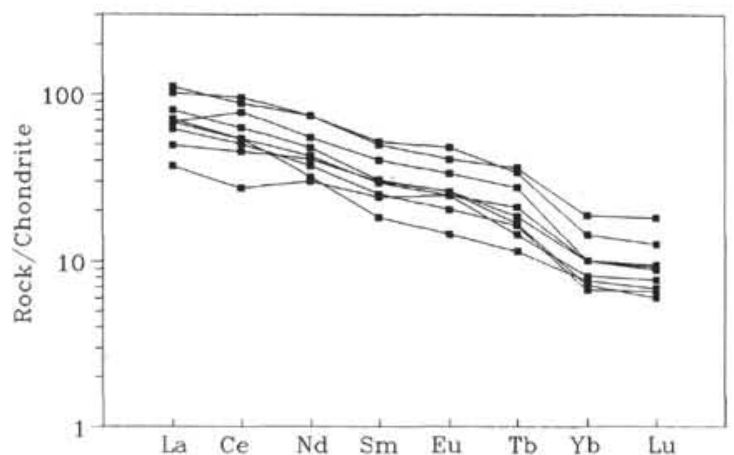

Figure 5. Rare earth elements of basalts from Hole 866A (Resolution Guyot), normalized to chondrite.

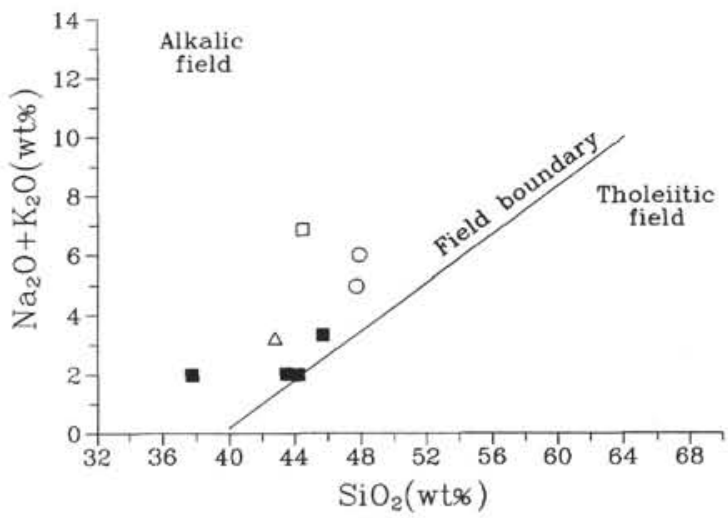

Figure 6. Macdonald's (1968) variation diagram of basalts from Hole 872B (Lo-En Guyot), Holes 874B and 876A (Wodejebato Guyot), and Hole 878A (MIT Guyot). Open circles $=$ Hole 872B, closed squares $=$ Hole 874B, open square $=$ Hole $876 \mathrm{~A}$, and open triangle $=$ Hole $878 \mathrm{~A}$.

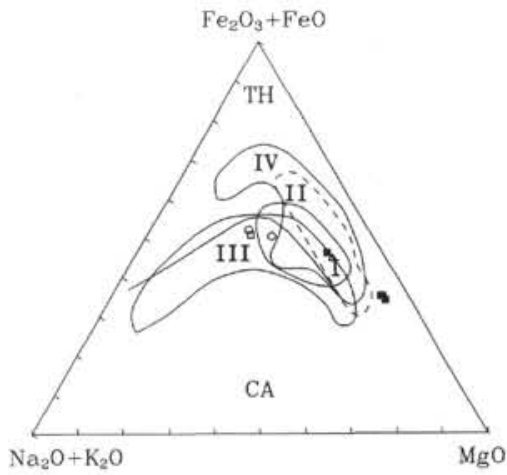

Figure 7. AFM diagram of basalts from Hole 872B (Lo-En Guyot), Holes 874B and 876A (Wodejebato Guyot), and Hole 876A (MIT Guyot). Symbols and fields are the same as in Figures 6 and 2, respectively. 
Table 5. Chemical analyses of basalts from Hole 866A (Resolution Guyot).

\begin{tabular}{|c|c|c|c|c|c|c|c|c|c|c|c|c|c|c|c|c|c|c|c|c|}
\hline & \multicolumn{2}{|c|}{1} & \multicolumn{2}{|c|}{2} & \multicolumn{2}{|c|}{3} & \multicolumn{2}{|c|}{4} & \multicolumn{2}{|c|}{5} & \multicolumn{2}{|c|}{6} & \multicolumn{2}{|c|}{7} & \multicolumn{2}{|c|}{8} & \multicolumn{2}{|c|}{9} & \multicolumn{2}{|c|}{10} \\
\hline & a & b & a & b & a & b & a & b & a & b & a & b & a & b & a & b & a & b & a & b \\
\hline \multicolumn{21}{|c|}{ Major element (wt\%): } \\
\hline $\mathrm{SiO}_{2}$ & 41.03 & 46.26 & 41.18 & 45.40 & 43.48 & 50.95 & 43.01 & 46.69 & 45.30 & 46.93 & 43.35 & 47.35 & 43.67 & 50.83 & 45.40 & 49.53 & 40.04 & 46.52 & 36.59 & 42.87 \\
\hline $\mathrm{TiO}_{2}^{2}$ & 3.38 & 3.81 & 3.67 & 4.05 & 2.55 & 2.99 & 3.59 & 3.90 & 3.40 & 3.52 & 2.99 & 3.27 & 1.95 & 2.27 & 2.57 & 2.80 & 3.47 & 4.03 & 3.11 & 3.64 \\
\hline $\mathrm{Al}_{2} \mathrm{O}_{3}$ & 20.13 & 22.70 & 18.83 & 20.76 & 15.05 & 17.64 & 15.54 & 16.87 & 14.95 & 15.49 & 13.76 & 15.03 & 13.78 & 16.04 & 11.03 & 12.03 & 16.08 & 18.68 & 18.47 & 21.64 \\
\hline $\mathrm{Fe}_{2} \mathrm{O}_{3}$ & 14.56 & 16.42 & 16.13 & 17.98 & 13.14 & 15.40 & 15.65 & 16.99 & 7.48 & 7.75 & 12.90 & 14.09 & 12.90 & 15.02 & 9.06 & 9.88 & 18.53 & 21.53 & 20.66 & 24.20 \\
\hline $\mathrm{FeO}$ & 0.88 & 0.99 & 0.63 & 0.69 & 0.38 & 0.45 & 1.73 & 1.88 & 5.33 & 5.52 & 2.34 & 2.56 & 0.43 & 0.50 & 2.78 & 3.03 & 0.12 & 0.14 & 0.16 & 0.19 \\
\hline $\mathrm{MnO}$ & 0.03 & 0.03 & 0.11 & 0.12 & 0.04 & 0.05 & 0.06 & 0.07 & 0.26 & 0.27 & 0.07 & 0.08 & 0.05 & 0.06 & 0.04 & 0.04 & 0.03 & 0.03 & 0.06 & 0.07 \\
\hline $\mathrm{MgO}$ & 1.54 & 1.74 & 2.52 & 2.78 & 4.78 & 5.60 & 3.25 & 3.53 & 6.30 & 6.53 & 6.68 & 7.30 & 5.12 & 5.96 & 12.35 & 13.47 & 2.85 & 3.31 & 2.83 & 3.32 \\
\hline $\mathrm{CaO}$ & 1.43 & 1.61 & 1.80 & 1.98 & 2.38 & 2.79 & 4.68 & 5.08 & 8.72 & 9.03 & 4.55 & 4.97 & 4.17 & 4.85 & 2.77 & 3.02 & 2.04 & 2.37 & $\begin{array}{l}1.48 \\
1.48\end{array}$ & 1.73 \\
\hline $\mathrm{Na}_{2} \mathrm{O}$ & 1.14 & $\begin{array}{l}1.29 \\
1.29\end{array}$ & $\begin{array}{l}1.00 \\
1.35\end{array}$ & 1.49 & 2.05 & 2.40 & 2.86 & 3.10 & $\begin{array}{l}0.76 \\
3.76\end{array}$ & 3.90 & 2.78 & 3.04 & 2.16 & 2.51 & 2.70 & 2.95 & 1.40 & 1.63 & $\begin{array}{l}1.19 \\
1.19\end{array}$ & 1.39 \\
\hline $\begin{array}{l}\mathrm{N}_{2} \mathrm{O} \\
\mathrm{K}_{2} \mathrm{O}\end{array}$ & $\begin{array}{l}1.14 \\
4.50\end{array}$ & 5.07 & 4.17 & $\begin{array}{l}1.49 \\
4.60\end{array}$ & 1.42 & $\begin{array}{l}2.60 \\
1.66\end{array}$ & $\begin{array}{l}2.80 \\
1.71\end{array}$ & $\begin{array}{l}3.86 \\
1.86\end{array}$ & 0.73 & 0.76 & 1.90 & 2.08 & 1.42 & 1.65 & 2.84 & 3.10 & 1.31 & $\begin{array}{l}1.53 \\
1.52\end{array}$ & 0.77 & 0.90 \\
\hline $\mathrm{P}_{2}^{2} \mathrm{O}_{5}$ & 0.07 & 0.08 & 0.13 & 0.14 & 0.07 & 0.08 & 0.04 & 0.04 & 0.29 & 0.30 & 0.24 & 0.26 & 0.26 & 0.30 & 0.13 & 0.14 & 0.20 & 0.23 & 0.04 & 0.05 \\
\hline $\begin{array}{l}2 \mathrm{O}_{5} \\
\mathrm{H}_{2} \mathrm{O}^{-}\end{array}$ & 3.55 & & 4.26 & & 9.02 & & 4.50 & & 1.78 & & 5.07 & & 7.98 & & 5.02 & & 7.95 & & 6.54 & \\
\hline $\mathrm{H}_{2} \mathrm{O}^{+}$ & 7.10 & & 5.43 & & 5.40 & & 2.85 & & 1.52 & & 2.50 & & 4.54 & & 3.20 & & 5.63 & & 6.23 & \\
\hline $\mathrm{Co}_{2}$ & & & & & & & & & & & 0.35 & & 1.10 & & & & & & & \\
\hline $\begin{array}{l}\text { Lof } \\
\text { Total }\end{array}$ & $\begin{array}{r}0.82 \\
100.16\end{array}$ & 100.00 & 100.39 & 100.00 & $\begin{array}{r}0.72 \\
100.48\end{array}$ & 100.00 & $\begin{array}{r}0.73 \\
100.20\end{array}$ & 100.00 & 99.82 & 100.00 & $\begin{array}{r}0.60 \\
100.08\end{array}$ & 100.00 & 99.53 & 100.00 & 99.89 & 100.00 & 99.65 & 100.00 & $\begin{array}{r}2.32 \\
100.45\end{array}$ & 100.00 \\
\hline \multicolumn{21}{|c|}{ Trace element (ppm): } \\
\hline & 735 & & 475 & & 140 & & 175 & & 195 & & 235 & & 130 & & 270 & & 430 & & 685 & \\
\hline $\mathrm{Ni}$ & 600 & & 470 & & 250 & & 155 & & 175 & & 220 & & 270 & & 180 & & 290 & & 430 & \\
\hline $\mathrm{V}$ & 230 & & 130 & & 230 & & 280 & & 360 & & 350 & & 130 & & 250 & & 215 & & 700 & \\
\hline $\mathrm{La}$ & 12 & & 16 & & 22 & & 33 & & 26 & & 23 & & 36 & & 20 & & 22 & & 21 & \\
\hline $\mathrm{Ce}$ & 22 & & 36 & & 43 & & 76 & & 50 & & 43 & & 70 & & 40 & & 62 & & 29 & \\
\hline $\mathrm{Nd}$ & 17 & & 23 & & 18 & & 42 & & 27 & & 24 & & 42 & & 21 & & 31 & & 24 & \\
\hline Sm & 4.5 & & 5.6 & & 3.4 & & 9.7 & & 5.7 & & 5.5 & & 9.3 & & 4.7 & & 7.5 & & 5.8 & \\
\hline $\mathrm{Eu}$ & 1.7 & & 1.8 & & 1.0 & & 3.3 & & 1.8 & & 1.7 & & 2.8 & & 1.4 & & 2.3 & & 1.9 & \\
\hline $\mathrm{Tb}$ & 0.68 & & 0.79 & & 0.54 & & 1.6 & & 0.87 & & 0.99 & & $\begin{array}{l}1.6 \\
1.7\end{array}$ & & 0.77 & & 1.3 & & 1.2 & \\
\hline $\begin{array}{l}10 \\
\mathrm{Yb}\end{array}$ & $\begin{array}{l}1.06 \\
1.7\end{array}$ & & 1.5 & & $\begin{array}{l}1.64 \\
1.6\end{array}$ & & $\begin{array}{l}1.0 \\
3.0\end{array}$ & & $\begin{array}{l}2.87 \\
2.1\end{array}$ & & 2.1 & & $\begin{array}{l}3.1 \\
3.9\end{array}$ & & 1.4 & & 2.1 & & $\begin{array}{l}1.2 \\
2.7\end{array}$ & \\
\hline $\mathrm{Lu}$ & 0.27 & & 0.21 & & 0.24 & & 0.43 & & 0.33 & & 0.32 & & 0.63 & & 0.23 & & 0.31 & & 0.41 & \\
\hline
\end{tabular}

Notes: Column a represents the real chemical composition, and column b represents the chemical composition recalculated for $100 \%$. Samples are as follows: $1=143-866 \mathrm{~A}-171 \mathrm{R}-2,109-111 \mathrm{~cm} ; 2=143-866 \mathrm{~A}-171 \mathrm{R}-4,131-134 \mathrm{~cm} ; 3=$ $143-866 \mathrm{~A}-182 \mathrm{R}-4,38-40 \mathrm{~cm} ; 4=143-866 \mathrm{~A}-182 \mathrm{R}-4,72-74 \mathrm{~cm} ; 5=143-866 \mathrm{~A}-184 \mathrm{R}-1,27-28 \mathrm{~cm} ; 6=143-866 \mathrm{~A}-184 \mathrm{R}-1,137-139 \mathrm{~cm} ; 7=143-866 \mathrm{~A}-184 \mathrm{R}-2,23-26 \mathrm{~cm} ; 8=143-866 \mathrm{~A}-186-1,39-41 \mathrm{~cm} ; 9=143-866 \mathrm{~A}-178 \mathrm{~W}-1,37-$ $38 \mathrm{~cm} ;$ and $10=143-866 \mathrm{~A}-178 \mathrm{~W}-1,79-81 \mathrm{~cm}$ 
Table 6. Chemical analyses of basalts from Hole 872B (Lo-En Guyot), Holes 874B, 875C, and 876A (Wodejebato Guyot), and Hole 878A (MIT Guyot).

\begin{tabular}{|c|c|c|c|c|c|c|c|c|c|c|c|c|c|c|c|c|}
\hline & \multicolumn{2}{|c|}{1} & \multicolumn{2}{|c|}{2} & \multicolumn{2}{|c|}{3} & \multicolumn{2}{|c|}{4} & \multicolumn{2}{|c|}{5} & \multicolumn{2}{|c|}{6} & \multicolumn{2}{|c|}{7} & \multicolumn{2}{|c|}{8} \\
\hline & a & b & a & b & a & b & a & b & a & b & a & b & a & b & a & b \\
\hline \multicolumn{17}{|c|}{ Major element (wt \%): } \\
\hline $\mathrm{SiO}_{2}$ & 41.90 & 47.87 & 45.58 & 47.72 & 39.14 & 44.24 & 30.51 & 37.72 & 38.00 & 43.51 & 42.86 & 45.70 & 38.96 & 44.49 & 40.42 & 42.80 \\
\hline $\mathrm{TiO}_{2}^{2}$ & 2.02 & 2.31 & 2.49 & 2.61 & 1.44 & 1.63 & 1.01 & 1.25 & 1.36 & 1.56 & 2.06 & 2.20 & 2.72 & 3.11 & 3.39 & 3.59 \\
\hline $\mathrm{Al}_{2} \mathrm{O}_{3}$ & 14.93 & 17.06 & 13.98 & 14.64 & 7.20 & 8.14 & 4.60 & 5.69 & 5.70 & 6.53 & 10.73 & 11.44 & 14.07 & 16.07 & 11.37 & 12.04 \\
\hline $\mathrm{Fe}_{2} \mathrm{O}_{3}$ & 10.99 & 12.56 & 7.77 & 8.13 & 7.62 & 8.61 & 8.07 & 9.98 & 10.38 & 11.89 & 8.57 & 9.14 & 12.01 & 13.71 & 5.66 & 5.99 \\
\hline $\mathrm{FeO}$ & 0.59 & 0.67 & 3.91 & 4.09 & 4.13 & 4.67 & 2.31 & 2.86 & 1.66 & 1.90 & 4.32 & 4.61 & 0.79 & 0.90 & 6.92 & 7.33 \\
\hline $\mathrm{MnO}$ & 0.03 & 0.03 & 0.07 & 0.07 & 0.07 & 0.08 & 0.07 & 0.09 & 0.07 & 0.08 & 0.07 & 0.07 & 0.10 & 0.11 & 0.10 & 0.11 \\
\hline $\mathrm{MgO}$ & 4.99 & 5.70 & 6.20 & 6.49 & 21.96 & 24.82 & 19.79 & 24.47 & 21.20 & 24.28 & 11.53 & 12.29 & 5.91 & 6.75 & 12.22 & 12.94 \\
\hline $\mathrm{CaO}$ & 6.28 & 7.17 & 10.47 & 10.96 & 4.46 & 5.04 & 12.84 & 15.88 & 7.05 & 8.07 & 10.34 & 11.02 & 6.82 & 7.79 & 10.32 & 10.93 \\
\hline $\mathrm{Na}_{2} \mathrm{O}$ & 2.86 & 3.27 & 3.42 & 3.58 & 1.40 & 1.58 & 1.45 & 1.79 & 1.56 & 1.79 & 2.28 & 2.43 & 3.36 & 3.84 & 1.82 & 1.93 \\
\hline $\mathrm{K}_{2} \mathrm{O}$ & 2.40 & 2.74 & 1.33 & 1.39 & 0.37 & 0.42 & 0.15 & 0.19 & 0.21 & 0.24 & 0.84 & 0.90 & 2.66 & 3.04 & 1.23 & 1.30 \\
\hline $\mathrm{P}_{2} \mathrm{O}_{5}$ & 0.54 & 0.62 & 0.30 & 0.31 & 0.69 & 0.78 & 0.08 & 0.10 & 0.14 & 0.16 & 0.19 & 0.20 & 0.17 & 0.19 & 0.98 & 1.04 \\
\hline $\mathrm{H}_{2} \mathrm{O}^{+}$ & 6.15 & & 2.02 & & 6.97 & & 6.02 & & 6.14 & & 3.61 & & 5.48 & & 3.8 & \\
\hline $\mathrm{H}_{2}^{-\mathrm{O}^{-}}$ & 5.00 & & 1.73 & & 4.12 & & 3.66 & & 5.10 & & 1.84 & & 4.28 & & 1.4 & \\
\hline $\mathrm{CO}_{2}$ & 1.80 & & 1.40 & & 0.85 & & 9.05 & & 1.30 & & 0.50 & & 2.40 & & & \\
\hline Total & 100.48 & 100.00 & 100.67 & 100.00 & 100.42 & 100.00 & 99.97 & 100.00 & 99.87 & 100.00 & 99.74 & 100.00 & 99.73 & 100.00 & 99.63 & 100.00 \\
\hline \multicolumn{17}{|c|}{ Trace element (ppm): } \\
\hline $\mathrm{Cr}$ & & & & & 840 & & 720 & & & & & & & & 240 & \\
\hline $\mathrm{Ni}$ & 90 & & 78 & & 900 & & 600 & & 740 & & 450 & & 95 & & 225 & \\
\hline V & 130 & & 230 & & 185 & & 60 & & 170 & & 255 & & 330 & & 230 & \\
\hline $\mathrm{La}$ & 24 & & 27 & & 13 & & 8.5 & & & & 19 & & 35 & & 43 & \\
\hline $\mathrm{Ce}$ & 45 & & 51 & & 27 & & 16 & & & & 38 & & 65 & & 87 & \\
\hline $\mathrm{Nd}$ & 19 & & 24 & & 14 & & 9 & & & & 18 & & 31 & & 43 & \\
\hline $\mathrm{Sm}$ & 4.2 & & 4.8 & & 3 & & 2 & & & & 4.2 & & 6.5 & & 9.1 & \\
\hline Eu & 1.5 & & 1.8 & & 0.87 & & 0.72 & & & & 1.4 & & 2.1 & & 2.8 & \\
\hline $\mathrm{Tb}$ & 0.69 & & 0.77 & & 0.51 & & 0.34 & & & & 0.67 & & 0.98 & & 1.3 & \\
\hline $\mathrm{Yb}$ & 1.2 & & 1.5 & & 0.94 & & 0.57 & & & & 1.4 & & 1.9 & & 2.0 & \\
\hline $\mathrm{Lu}$ & 0.16 & & 0.23 & & 0.15 & & 0.088 & & & & 0.2 & & 0.25 & & 0.25 & \\
\hline
\end{tabular}

Notes: Column a represents the real chemical composition, and column b represents the chemical composition recalculated for $100 \%$. Samples are as follows: $1=144-872 \mathrm{~B}-8 \mathrm{R}-2,9-12 \mathrm{~cm} ; 2=144-872 \mathrm{~B}-8 \mathrm{R}-2,91-94 \mathrm{~cm} ; 3=144-874 \mathrm{~B}-$ $24 \mathrm{R}-1,108-110 \mathrm{~cm} ; 4=144-874 \mathrm{~B}-24 \mathrm{R}-1,115-118 \mathrm{~cm} ; 5=144-874 \mathrm{~B}-24 \mathrm{R}-2,74-77 \mathrm{~cm} ; 6=144-874 \mathrm{~B}-24 \mathrm{R}-4,54-72 \mathrm{~cm} ; 7=144-876 \mathrm{~A}-15 \mathrm{R}-1,32-34 \mathrm{~cm} ;$ and $8=144-878 \mathrm{~A}-84 \mathrm{R}-3,112-115 \mathrm{~cm}$. 

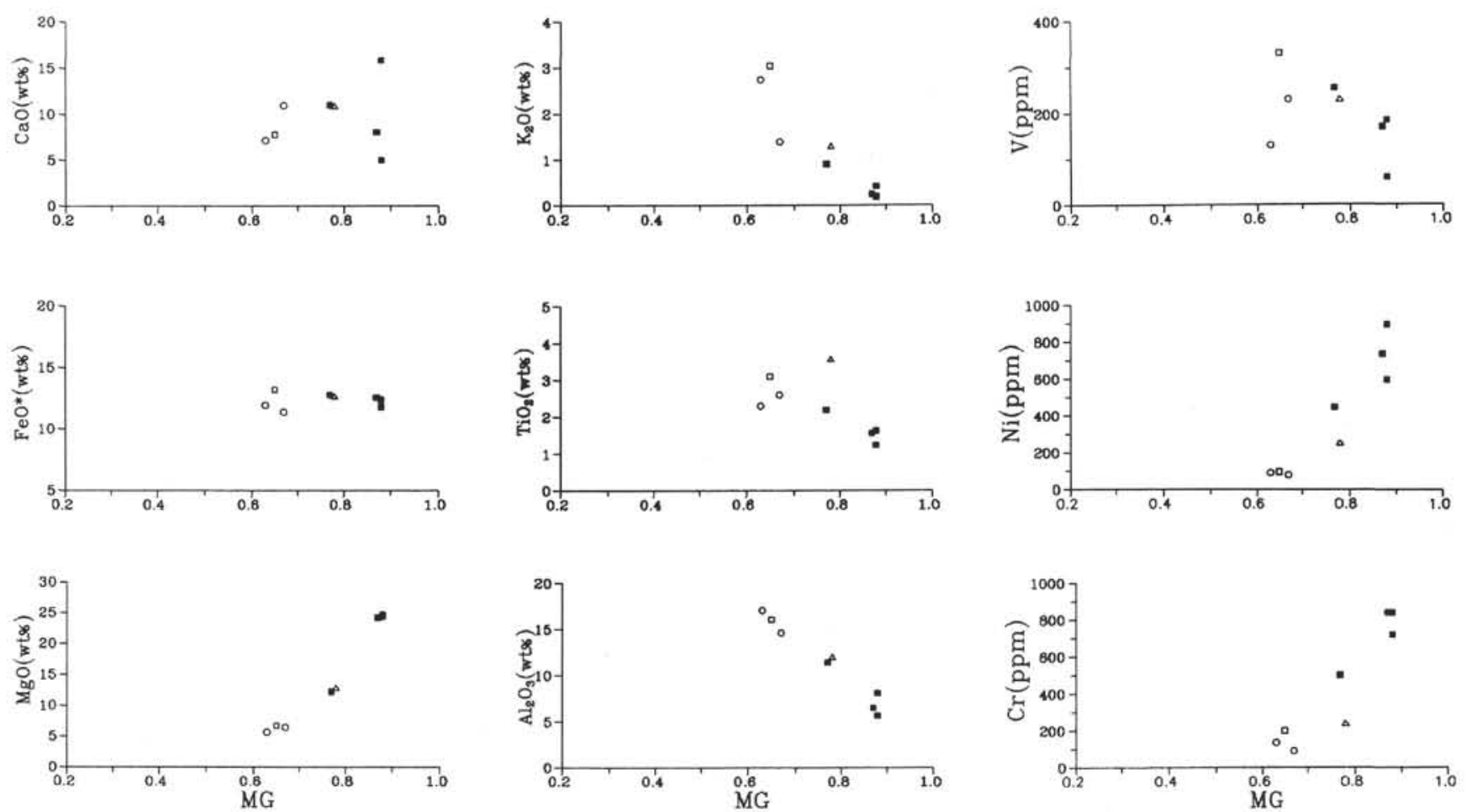

Figure 8. Variation diagrams for major and minor elements vs. $\mathrm{MG}=\mathrm{Mg} /\left(\mathrm{Mg}+\mathrm{Fe}^{2+}\right)$ of basalts from Hole $872 \mathrm{~B}$ (Lo-En Guyot) and Holes $874 \mathrm{~B}$ and $876 \mathrm{~A}$ (Wodejebato Guyot). Symbols are the same as in Figure 6.

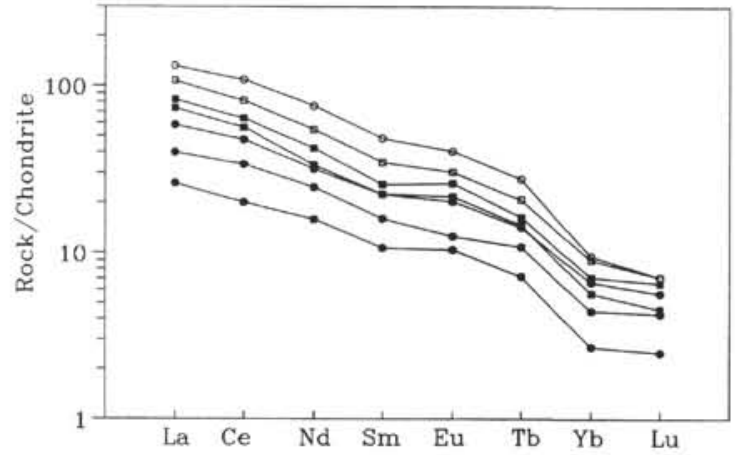

Figure 9. Rare earth elements in basalts from Hole 872B (Lo-En Guyot), Holes 874B and 876A (Wodejebato Guyot), and Hole 878A (MIT Guyot), normalized to chondrite. Closed squares $=$ Hole $872 \mathrm{~B}$, closed circles $=$ Hole $874 \mathrm{~B}$, open squares $=$ Hole $876 \mathrm{~A}$, and open circles $=$ Hole $878 \mathrm{~A}$.

cations, or by calcite with traces of quartz. Amygdale walls are commonly encrusted by smectite.

\section{Resolution Guyot (Hole 866A)}

The basalts of Resolution Guyot are moderately to very strongly altered $\left(\mathrm{H}_{2} \mathrm{O}^{+}\right.$ranges from 1.4 to $7 \mathrm{wt} \%$; Table 2). The predominate secondary mineral is smectite with interlayer cations of $\mathrm{Na}$ and $\mathrm{K}$. The smectite replaces olivine, groundmass glass, plagioclase, and pyroxene, and commonly forms pseudomorphs. Smectites are represented by different varieties, from pure to those containing about $10 \%$ mica layers. The smectite also infills vesicles and thin fissures (Table 2). SEM photomicrographs show interstitial glass and olivine replaced by smectite (Plate 3, Figs. 1,2), as well as filled vesicles (Plate 3, Fig. 3). Other clay minerals identified include common kaolinite, rare hydromica, and chlorite.
The non-clay alteration products include calcite, ankerite, hematite, quartz, gypsum, an unidentified $3.51 \AA$-mineral, and the $4.87 \AA$ mineral. Calcite replaces central parts of olivine phenocrysts and infills vesicles, where it occurs together with ankerite. Hematite was found in veinlets and vesicles, as an alteration product of groundmass glass and olivine.

Unlike in Hole $865 \mathrm{~A}$, there were no complete sample sets across any of the flow units recovered in Hole 866A. Instead, the samples have been taken either from the top or from the bottom of the units (Fig. 11).

Smectite predominates among the alteration products throughout the basalt sequence. This is the variety with $\mathrm{Na}-\mathrm{K}$ interlayer cations in all cases, except for Sample 143-866A-186R-1, 39-41 cm (Unit 11), where smectite is represented by $\mathrm{Ca}-\mathrm{Mg}$ interlayer cations. The $\mathrm{MgO}$ content in the sample is as high as $12 \mathrm{wt} \%$ (Table 5); the $\mathrm{MgO} /(\mathrm{MgO}$ $+\mathrm{Fe}_{2} \mathrm{O}_{3}+\mathrm{FeO}$ ) ratio is correspondingly high (Fig. 11). Note that the altered basalts having similar chemical patterns from Hole $865 \mathrm{~A}$ contain swelling chlorite and mixed-layer smectite-chlorite. In the upper half of the basalt sequence, kaolinite ranges from minor to dominant among the clay minerals (Sample 143-866A-171R-2, 109-111 cm), being associated with a high level of alteration (weathering), as indicated by $\mathrm{H}_{2} \mathrm{O}^{+}$of more than $5 \mathrm{wt} \%$ and by an $\mathrm{Al}_{2} \mathrm{O}_{3} / \mathrm{SiO}_{2}$ ratio of more than 0.4 (Fig. 11). Hematite was found in all samples studied, corresponding with a high oxidation state $\left(\mathrm{Fe}_{2} \mathrm{O}_{3} /\left[\mathrm{Fe}_{2} \mathrm{O}_{3}+\mathrm{FeO}\right]\right)$.

\section{Lo-En Guyot (Hole 872B)}

Thin sections and XRD of the clay fractions extracted from basalts of Unit 16 show that the volcanic rocks are moderately to very strongly altered (Table 3). The dominating secondary mineral is smectite with interlayer $\mathrm{Ca}-\mathrm{Mg}$ cations. The smectite replaces groundmass glass, biotite microaggregates, plagioclase, and pyroxene. The non-clay alteration products include calcite, chabazite, and an unidentified $4.87 \AA$-mineral. Calcite and smectite replace groundmass glass, infills vesicles and, together with zeolite, infills microfissures. 


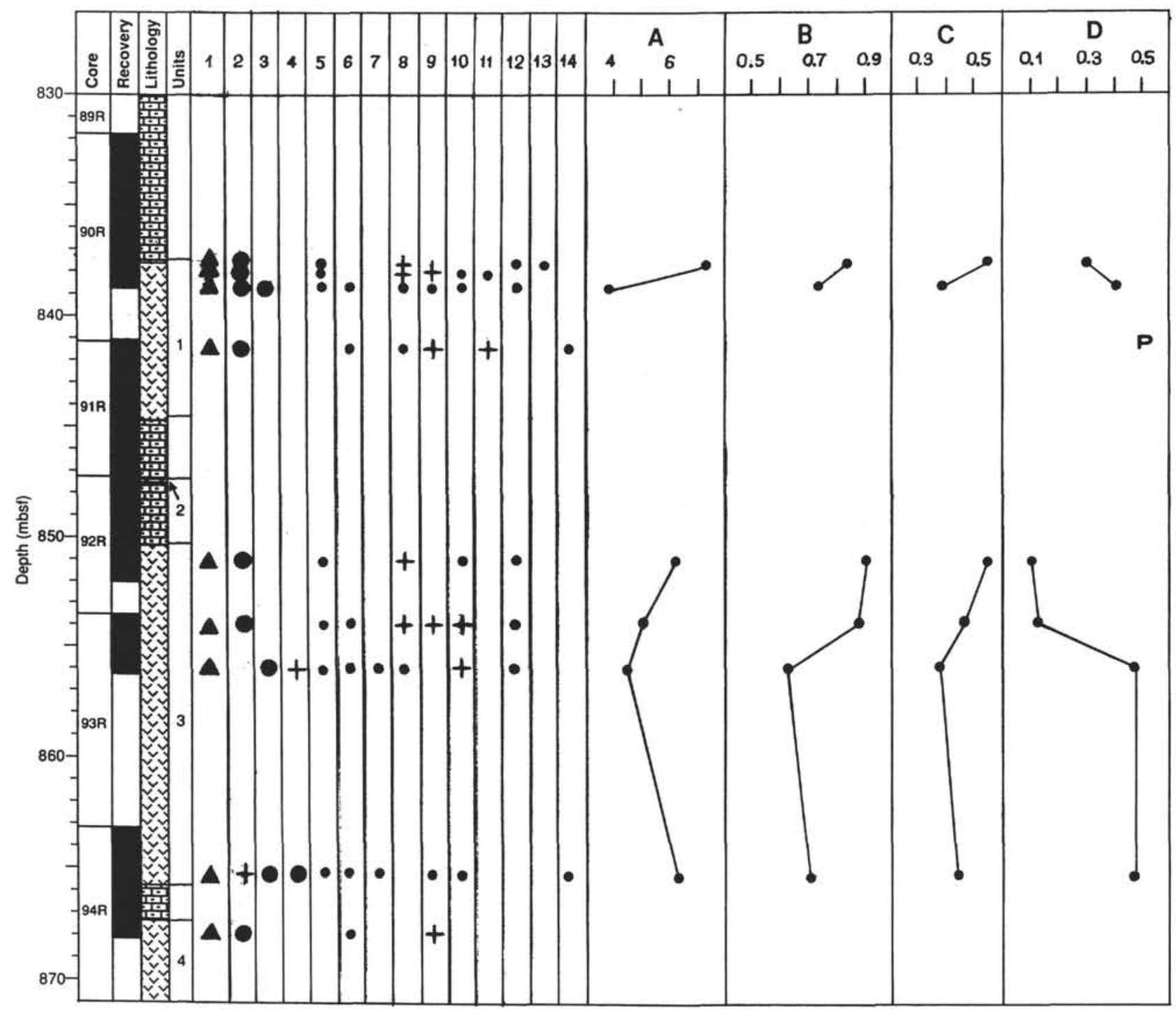

Figure 10. Distribution of secondary minerals and the chemical data for altered basalts for Hole $865 \mathrm{~A}$ (Allison Guyot). $1=$ sample locations. Minerals: $2=$ smectite, $3=$ swelling chlorite, $4=$ mixed layer smectite-chlorite, $5=$ hydromica, $6=$ chlorite, $7=$ serpentine, $8=$ kaolinite, $9=$ calcite, $10=$ hematite, $11=$ quartz, $12=$ gypsum, $13=2.79 \AA$-mineral, and $14=3.51 \AA$-mineral. Chemical data and ratios: $\mathrm{A}=\mathrm{H}_{2} \mathrm{O}^{+}$wt $\%, \mathrm{~B}=\mathrm{Fe}_{2} \mathrm{O}_{3} /\left(\mathrm{Fe}_{2} \mathrm{O}_{3}+\mathrm{FeO}\right), \mathrm{C}=\mathrm{Al}_{2} \mathrm{O}_{3} / \mathrm{SiO}{ }_{2}$, and D $=\mathrm{MgO} /(\mathrm{MgO}$ $\left.+\mathrm{Fe}_{2} \mathrm{O}_{3}+\mathrm{FeO}\right)$. Large solid circle $=$ dominant, plus sign $(+)=$ minor, and small solid circle $=$ trace.

Unit 16 is single flow with a relatively thick flow-top breccia (about $2 \mathrm{~m}$ ) above a massive base (thickness is about $3 \mathrm{~m}$ ). Two samples (144-872B-8R-1, 50-54 cm, and -8R-2, 9-12 cm) were taken from the flow-top breccia. Sample 144-872B-8R-2, 91-94 cm, is from the upper part of the massive basalt. The main secondary minerals are smectite, calcite, and hematite in both the brecciated and massive basalt.

The flow-top breccia is strongly altered and oxidized: $\mathrm{H}_{2} \mathrm{O}^{+}$is more than $6 \mathrm{wt} \%$, and the $\mathrm{Fe}_{2} \mathrm{O}_{3} /\left(\mathrm{Fe}_{2} \mathrm{O}_{3}+\mathrm{FeO}\right)$ ratio is 0.95 . However, the $\mathrm{Al}_{2} \mathrm{O}_{3} / \mathrm{SiO}_{2}$ ratio of 0.36 is similar to that found in the basal part having no subaerial weathering in Holes $865 \mathrm{~A}$ and $866 \mathrm{~A}$. The massive basalt from the central part of Unit 16 (just below the breccia) is moderately altered and oxidized: $\mathrm{H}_{2} \mathrm{O}^{+}$is about $2 \mathrm{wt} \%$ and the $\mathrm{Fe}_{2} \mathrm{O}_{3} /\left(\mathrm{Fe}_{2} \mathrm{O}_{3}+\mathrm{FeO}\right)$ ratio is 0.66 . The ratio of $\mathrm{Al}_{2} \mathrm{O}_{3} / \mathrm{SiO}_{2}$ is low (0.31).

\section{Wodejebato Guyot (Holes 874B, 875C, and 876A)}

The basalts of the Wodejebato Guyot are moderately to very strongly altered $\left(\mathrm{H}_{2} \mathrm{O}^{+}\right.$ranges from 3.6 to $6.97 \mathrm{wt} \%$; Table 6). The dominating secondary mineral is smectite; mixed-layer smectite-chlorite and serpentine range from trace to minor. The secondary minerals replace olivine, groundmass glass, plagioclase, and pyroxene, and commonly form pseudomorphs. Smectite infills vesicles and thin fissures. Chlorite and hydromica were identified as traces. The non-clay alteration products include calcite, chabazite, and rare quartz. Calcite with smectite replaces olivine phenocrysts and infills fissures, often together with chabazite.

Hole $874 \mathrm{~B}$ penetrated a single ankaramite flow $15.8 \mathrm{~m}$ thick (Unit 1). Four samples were studied from the lower half of the unit. Basalts (Samples 144-874B-24R-1, 108-110 cm, -24R-1, 115-118 cm, and $-24 \mathrm{R}-2,74-77 \mathrm{~cm}$ ) are very strongly altered as indicated by $\mathrm{H}_{2} \mathrm{O}^{+}$of more than $6 \mathrm{wt} \%$ (Table 6). The dominating secondary minerals in these basalts, which have a high $\mathrm{MgO}$ content (19.8-22 wt\%; Table 6 ), are smectite with $\mathrm{Ca}-\mathrm{Mg}$ interlayer cations, mixed-layer smectitechlorite, and smectite-swelling chlorite, as well as variable amounts of serpentine. Chlorite occurs as traces. Calcite infills fissures.

In the lowermost sample from Unit 1 (Sample 144-874B-24R-4, $54-72 \mathrm{~cm}$ ), the basalt has a lower $\mathrm{MgO}$ content (11.5 wt\%; Table 6) 


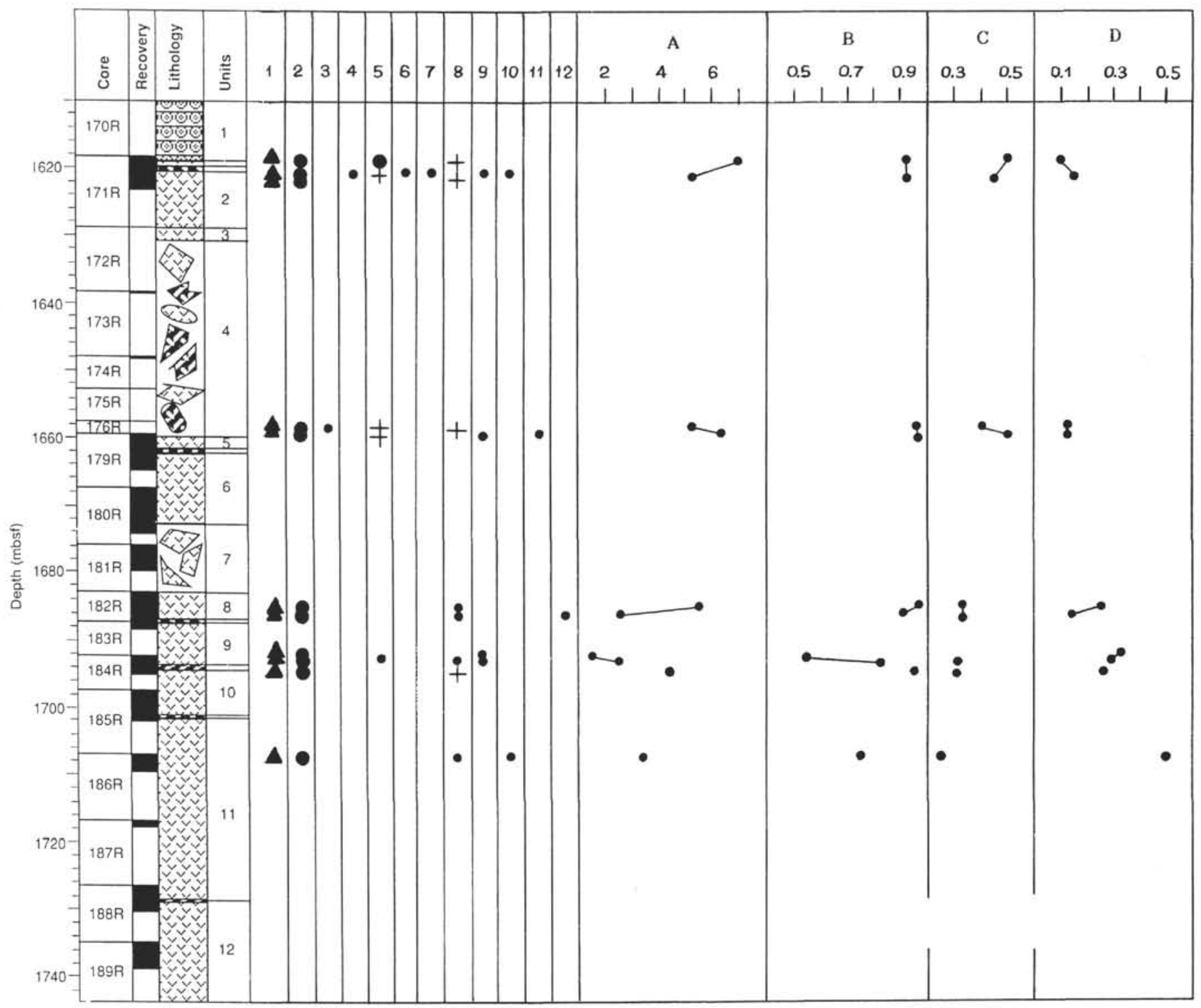

Figure 11. Distribution of secondary minerals and the chemical data for altered basalts for Hole $866 \mathrm{~A}$ (Resolution Guyot). $1=$ sample locations. Minerals: $2=$ smectite, 3 = hydromica, $4=$ chlorite, $5=$ kaolinite, $6=$ calcite, $7=$ ankerite, $8=$ hematite, $9=$ quartz, $10=$ gypsum, $11=3.51 \AA$-mineral, and $12=4.87 \AA-$ mineral. Chemical data and ratios: $\mathrm{A}=\mathrm{H}_{2} \mathrm{O}^{+} \mathrm{wt} \%, \mathrm{~B}=\mathrm{Fe}_{2} \mathrm{O}_{3} /\left(\mathrm{Fe}_{2} \mathrm{O}_{3}+\mathrm{FeO}\right), \mathrm{C}=\mathrm{Al}_{2} \mathrm{O}_{3} / \mathrm{SiO}_{2}$, and $\mathrm{D}=\mathrm{MgO} /\left(\mathrm{MgO}+\mathrm{Fe}_{2} \mathrm{O}_{3}+\mathrm{FeO}\right)$. Large solid circle $=$ dominant, plus $\operatorname{sign}(+)=$ minor, and small solid circle $=$ trace.

and contains mainly smectite. Chlorite and mixed-layer smectiteswelling chlorite occur only as traces. Serpentine is absent. Some high values of $\mathrm{Na}_{2} \mathrm{O}(2.28 \mathrm{wt} \%)$ and $\mathrm{K}_{2} \mathrm{O}(0.84 \mathrm{wt} \%)$ (Table 6) are accompanied by the appearance of smectite, with $20 \%$ mica layers in fissures and hydromica as trace in vesicles. Basalt is moderately altered $\left(\mathrm{H}_{2} \mathrm{O}^{+}=3.6 \mathrm{wt} \%\right)$.

A single flow (approximately $85 \mathrm{~cm}$ ) was recovered in Hole $875 \mathrm{C}$ (Sample 144-875C-15M-1, 35-37 cm). Hole 876A drilled the 14.5-mthick basaltic interval and recovered approximately $2.2 \mathrm{~m}$. Samples 144-876A-15R-1, 32-34 cm, and -16R-1, 6-8 cm, are from Unit 1 . Basalts from Holes $875 \mathrm{C}$ and $876 \mathrm{~A}$ are moderately to very strongly altered $\left(\mathrm{H}_{2} \mathrm{O}^{+}\right.$up to $5.5 \mathrm{wt} \%$; Table 6$)$ and strongly oxidized $\left(\mathrm{Fe}_{2} \mathrm{O}_{3} /\right.$ $\left.\left[\mathrm{Fe}_{2} \mathrm{O}_{3}+\mathrm{FeO}\right]=0.94\right)$. The dominant secondary mineral is smectite with $20 \%-40 \%$ mica layers. Mixed-layer smectite-chlorite was found as a minor component; chlorite and hydromica occur as traces. Calcite, with chabazite and a trace of quartz, infills fissures. Vesicles are infilled mainly by smectite with $30 \%-40 \%$ mica interlayers.

\section{MIT Guyot (Hole 878A)}

At Hole 878A (MIT Guyot), we received a single sample (144878A-84R-3, 112-115 cm) taken from the central part of Unit 15 (thickness of the unit is about $9 \mathrm{~m}$ ). The basalt is moderately altered $\left(\mathrm{H}_{2} \mathrm{O}^{+}\right.$content $=3.8 \mathrm{wt} \%$; Table 6$)$. The dominant secondary mineral is smectite with $\mathrm{Ca}-\mathrm{Mg}$ interlayer cations and a $20 \%$ mica layer. Hydromica, chlorite, and mixed-layer smectite-chlorite occur as traces. The secondary minerals replace olivine, pyroxene, and plagioclase. The smectite (with chlorite as trace) infills fissures and vesicles.

\section{DISCUSSION}

Alkaline basalts of the Allison, Resolution, Lo-En, Wodejebato, and MIT guyots are typical lavas of intraplate volcanism. Similar basalts from the Emperor Seamount Chain were studied by Kirkpatrick et al. (1980), Avdeiko et al. (1980), and Clague and Frey (1980). 
Basalts are strongly altered, so their primary composition cannot be reconstructed using only petrographic and geochemical data, but the latter data are necessary to interpret the alteration products in the samples studied.

Basalts from the Allison Guyot generally are strongly to very strongly altered by low-temperature smectitization mainly in the upper parts of the units and by chloritization (swelling chlorite and mixedlayer smectite-chlorite) in the central and lower parts of the units. Similar distribution of the secondary minerals was previously recognized in Unit 48 (olivine basalts) from Suiko Guyot in the Emperor Seamount Chain (DSDP Leg 55, Hole 433C; Kurnosov, 1986). The difference can be explained either by higher magnesium content in the central parts of the units (Units 1 and 3; Fig. 10) or by higher temperature of alteration within sills.

The assemblage of secondary minerals in the central parts of the basalt units from Hole $865 \mathrm{~A}$ suggests low-temperature to relatively high-temperature (within sills) hydrothermal alteration. The assemblage at the top of Units 1 and 3, which is composed of kaolinite, smectite and hematite, however, is most likely created by subaerial weathering in oxidizing conditions (as shown by the high state of iron oxidation) accompanied by leaching of silica (increase in the $\mathrm{Al}_{2} \mathrm{O}_{3} /$ $\mathrm{SiO}_{2}$ ratio up to 0.55 ) and magnesium (decrease in the $\mathrm{MgO} /[\mathrm{MgO}+$ $\mathrm{Fe}_{2} \mathrm{O}_{3}+\mathrm{FeO}$ ] ratio) from the basalts (Fig. 10).

Basalts from the upper $40 \mathrm{~m}$ of the Resolution Guyot basement sequence recovered in Hole $866 \mathrm{~A}$ are strongly to very strongly altered, similar to those from the Allison Guyot. The low-temperature alteration is dominated by smectitization. Kaolinitization is strong to moderate. Chemically, this process is marked by high water content (more than $5 \mathrm{wt} \% \mathrm{H}_{2} \mathrm{O}^{+}$), by a high oxidation state $\left(\mathrm{Fe}_{2} \mathrm{O}_{3} /\left[\mathrm{Fe}_{2} \mathrm{O}_{3}+\right.\right.$ $\mathrm{FeO}$ ] above 0.9$)$, by an increased $\mathrm{Al}_{2} \mathrm{O}_{3} / \mathrm{SiO}_{2}$ ratio $(0.4-0.5)$, and by a low $\mathrm{MgO} /\left(\mathrm{MgO}+\mathrm{Fe}_{2} \mathrm{O}_{3}+\mathrm{FeO}\right.$ ) ratio (about 0.1) (Fig. 11).

The lower half of the basalt sequence recovered in Hole 866A (below $1660 \mathrm{mbsf}$ ) is somewhat less altered than the upper one (strong to moderate alteration). However, the alteration products are also dominated by smectite, despite the relatively high $\mathrm{MgO} /(\mathrm{MgO}+$ $\mathrm{Fe}_{2} \mathrm{O}_{3}+\mathrm{FeO}$ ) value $(0.5)$. This is similar to the middle parts of the flow units in Hole $865 \mathrm{~A}$ basalts, where chlorite and mixed-layer smectite-chlorite are formed. The differences in secondary mineralogy between chemically similar basalts are probably caused by a lower temperature of alteration on the Resolution Guyot.

The latter assumption is consistent with the different character of volcanic eruptions suggested by the Shipboard Scientific Party (Sager, Winterer, Firth, et al., 1993): intrusion of shallow sills into lagoonal sediments on the Allison Guyot and subaerial lava flows on the Resolution Guyot. Alteration in the inner zones of the sills on Allison Guyot probably took place during longer posteruptive cooling in a semiclosed hydrothermal system. Lava flows on the Resolution Guyot were altered at a lower temperature than the inner parts of sills on the Allison Guyot.

Alteration of the lava flows on the Resolution Guyot was a typical result of lateritic-type subaerial weathering in warm (tropical) climatic conditions (Karpoff, 1980; Murdmaa et al., 1980). The weathering is indicated by the smectite-kaolinite clay mineral assemblage with persistent hematite, as well as by a high oxidation state and an increase in the $\mathrm{Al}_{2} \mathrm{O}_{3} / \mathrm{SiO}_{2}$ ratio that was caused by silica leaching. Similar mineralogical and chemical patterns were also found in the upper zones of two basalt units on the Allison Guyot, suggesting weathering on the sill surface, possibly during temporary emergence above sea level. An alternative explanation is either early diagenetic or low-temperature hydrothermal alteration of the sill upper surface within water-saturated and oxygenated lagoonal sediments.

The kaolinite-smectite clay mineral assemblage also was found in clayey interbeds within the shallow-water (lagoonal) sequence on both guyots and is interpreted as being derived from soils formed on exposed basalts during weathering (Murdmaa and Kurnosov, this volume).

Basalts from the Lo-En Guyot have undergone low-temperature smectitization with the formation of calcite and chabazite in fissures.
Basalts from flow-top breccia are very strongly altered $\left(\mathrm{H}_{2} \mathrm{O}^{+}\right.$about $6 \mathrm{wt} \%)$ and oxidized $\left(\mathrm{Fe}_{2} \mathrm{O}_{3} /\left[\mathrm{Fe}_{2} \mathrm{O}_{3}+\mathrm{FeO}\right]=0.95\right)$ under subaerial conditions.

An ankaramite flow on Wodejebato Guyot (Hole 874B) is very strongly altered in the lower half by low-temperature smectitization and by chloritization (mixed-layer smectite-chlorite and smectiteswelling chlorite). Furthermore, serpentine is present in variable amounts. The smectite with interlayer cations of $\mathrm{Mg}$, mixed-layer smectite-chlorite, serpentine, and chlorite represent an assemblage possibly formed in basalts with very high primary magnesium content. This conclusion is confirmed by the absence of serpentine and by minor to trace amounts of mixed-layer smectite-chlorite in Sample 144-874B-24R-4, 54-72 cm, from the same lava flow, but with lower magnesium content $(\mathrm{MgO}=11.5 \mathrm{wt} \%)$. In this case, chlorite phases and serpentine reflect very high magnesium content in the rock rather than higher temperature.

Basalts of the Wodejebato Guyot recovered in Holes $875 \mathrm{C}$ and $876 \mathrm{~A}$ are moderately to very strongly altered by low-temperature smectitization with calcite formation in fissures and chabazite in some samples. The persistent presence of hydromica in basalts can be explained by higher primary alkaline element content. The basalt studied is strongly oxidized in subaerial conditions.

Basalts of the MIT Guyot were poorly sampled for our study. We had only one sample from a 187 -m-thick sequence penetrated by Hole $878 \mathrm{~A}$, with 24 flows of hawaiite, basanite, and alkali olivine basalts and with at least 3 periods of weathering. Our sample (basanite) characterizes low-temperature smectitization of phyric pyroxene-olivine basalt in the central part of Unit 15 with a moderate level of alteration.

As a whole, the alteration conditions and products correspond to the results obtained by detailed study of altered basalts from the Emperor Seamounts drilled during DSDP Leg 55 (Kirkpatrick et al., 1980; Kurnosov, 1986). Dominating smectites among alteration products suggest the smectite facies of basalt alteration in oceanic crust (Kurnosov, 1986).

\section{CONCLUSIONS}

Petrographic and geochemical results show that volcanic rocks of the Allison, Resolution, Lo-En, Wodejebato, and MIT guyots are alkaline intraplate basalts with very weak differentiation of the hawaiite-mugearite type.

Two processes of basalt alteration have been suggested from the study results: low-temperature hydrothermal alteration and weathering. The low-temperature hydrothermal alteration is indicated by smectite, swelling chlorite, and mixed-layer smectite-chlorite, as well as serpentine, chlorite, and hydromica associated with carbonates (mainly calcite, with rare ankerite), chabazite, gypsum, and rare quartz. The laterite weathering led to formation of kaolinite-smectite association with hematite.

The differences in low-temperature hydrothermal mineral assemblages depend on the chemical composition of primary basalt, rather than on different temperatures of alteration. Increasing magnesium content in basalts is accompanied by the appearance, along with smectite, of mixed-layer smectite-chlorite and even of serpentine. Higher content of alkaline elements in primary basalts possibly leads to formation of hydromica. Similar dependence on primary basalt composition was found in the Emperor Seamount Chain (Kurnosov, 1986).

Lateritic weathering is developed throughout the basalt flow sequence recovered from Hole 866A (Resolution Guyot). It is stronger in the upper part of the sequence and weaker in the lower part; similar weathering products were found at the tops of the two upper sill units on the Allison Guyot. The weathering results in oxidation and the leaching of silica and $\mathrm{Mg}$, the latter only from the upper zones.

Basalts from flow-top breccia on the Lo-En Guyot are altered and oxidized under subaerial conditions but without the features typical of lateritic weathering, such as kaolinite formation and silica leaching. The same was observed on the Wodejebato Guyot in Hole 876A. 


\section{ACKNOWLEDGMENTS}

We thank the reviewers for useful critical remarks. We also would like to thank O. Chudaev for help with analyses; A. Sokolova and E. Pokrovskaya (XRD); N. Kalashnicova and E. Cherkasova (chemical analysis); S. Liapunov (XRF and neutron-activation analysis); N. Gorkova (SEM), N. Barinov and G. Yudina (electron microscopy and electron diffraction analysis); and G. Narnov (infrared spectroscopy).

\section{REFERENCES}

Avdeiko, G.P., Khubunaja, S.A., and Vande-Kirkov, J.V., 1980. Petrography and chemical composition of the lava flows from the Emperor Seamounts, DSDP Leg 55. Init. Repts. DSDP, 55: Washington (U.S. Govt. Printing Office), 571-584.

Baker, P.E., Castillo, P.R., and Condliffe, E., 1995. Petrology and geochemistry of igneous rocks from Allison and Resolution Guyots, Sites 865 and 866. In Winterer, E.L., Sager, W.W., Firth, J.V., and Sinton, J.M. (Eds.), Proc. ODP, Sci. Results, 143: College Station, TX (Ocean Drilling Program), $245-261$.

Bass, M.N., 1976. Secondary minerals in oceanic basalt, with special reference to Leg 34, Deep Sea Drilling Project. In Yeats, R.S., Hart, S.R., et al., Init. Repts. DSDP, 34: Washington (U.S. Govt. Printing Office), 393-432.

Bass, M.N., Moberly, R., Rhodes, J.M., Shih, C.C., and Church, S.E., 1973. Volcanic rocks cored in the central Pacific, Leg 17, Deep Sea Drilling Project. In Winterer, E.L., Ewing, J.I., et al., Init. Repts. DSDP, 17: Washington (U.S. Govt. Printing Office), 429-503.

Clague, D.A., and Frey, F.A., 1980. Trace-element geochemistry of tholeiitic basalts from Site 433C, Suiko seamount. In Jackson, E.D., Koizumi, I., et al., Init. Repts. DSDP, 55: Washington (U.S. Govt. Printing Office), 559-569.

Gladney, E.S., and Roelandts, I., 1988. 1987 compilation of elemental concentration data from USGS BHVO-1, MAG-1, QLO-1, RGM-1, SCo-1, SDC-1, SGR-1 and STM-1. Geostand. Newsl., 12:253-262.
Karpoff, A.M., 1980. The claystone layer between two basalt flows in Hole 432A: an argument for the emergence of Nintoku Seamount. In Jackson, E.D., Koizumu, I., et al., Init. Repts. DSDP, 55: Washington (U.S. Govt. Printing Office), 707-711.

Kirkpatrick, R.J., Clague, D.A., and Freisen, W., 1980. Petrology and geochemistry of volcanic rocks, DSDP Leg 55, Emperor Seamount Chain. In Jackson, E.D., Koizumi, I., et al., Init. Repts. DSDP, 55: Washington (U.S. Govt. Printing Office), 509-557.

Kurnosov, V.B., 1986. Hydrothermal Alterations of Basalts in the Pacific Ocean and Metal-bearing Deposits, Using Data of Deep-sea Drilling: Moscow (Nauka).

Macdonald, G.A., 1968. Composition and origin of Hawaiian lavas. Contrib. Hawaii Inst. Geophys. Year, 477-552.

Murdmaa, I.O., Gordeev, V.V., Kuzmina, T.G., Turanskaya, N.V., and Avdeiko, G.P., 1980. Geochemistry of the Leg 55 sediments. In Jackson, E.D., Koizumi, I., et al., Init. Repts. DSDP, 55: Washington (U.S. Govt. Printing Office), $457-462$.

Premoli Silva, I., Haggerty, J., Rack, F., et al., 1993. Proc. ODP, Init. Repts., 144: College Station, TX (Ocean Drilling Program).

Sager, W.W., Winterer, E.L., Firth, J.V., et al., 1993. Proc. ODP, Init. Repts., 143: College Station, TX (Ocean Drilling Program).

\footnotetext{
- Abbreviations for names of organizations and publications in ODP reference lists follow the style given in Chemical Abstracts Service Source Index (published by American Chemical Society).
}

Date of initial receipt: 26 January 1994

Date of acceptance: 15 September 1994

Ms 144SR-068 


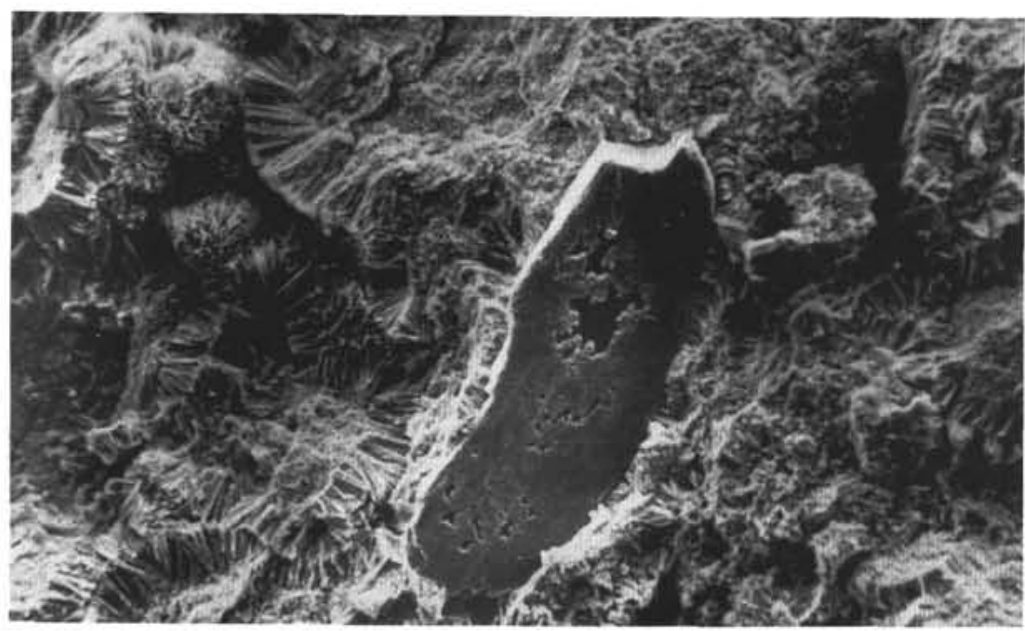

1

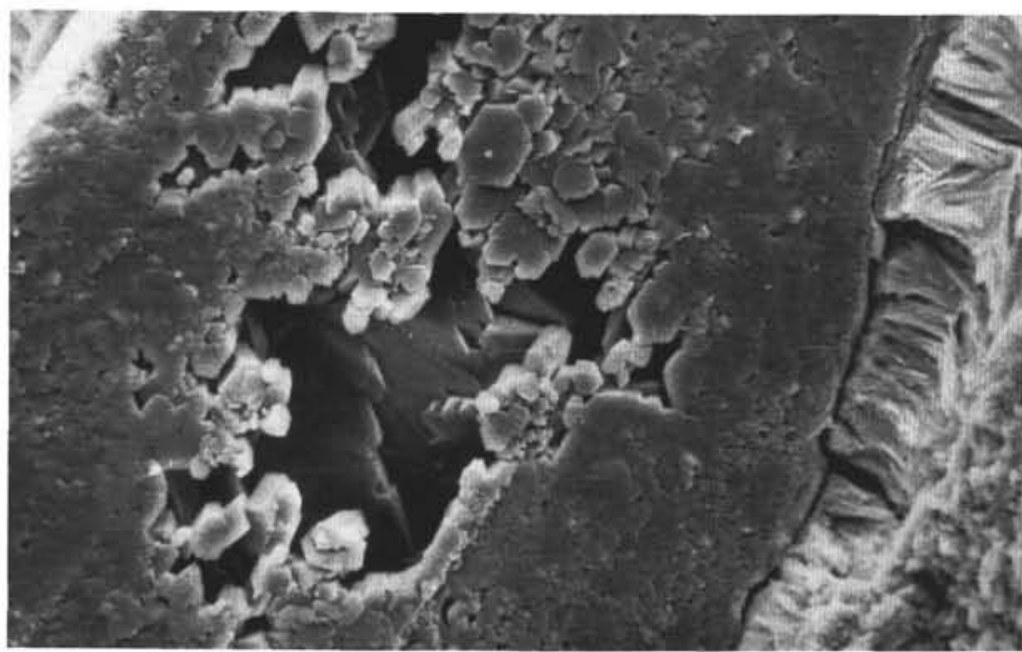

2

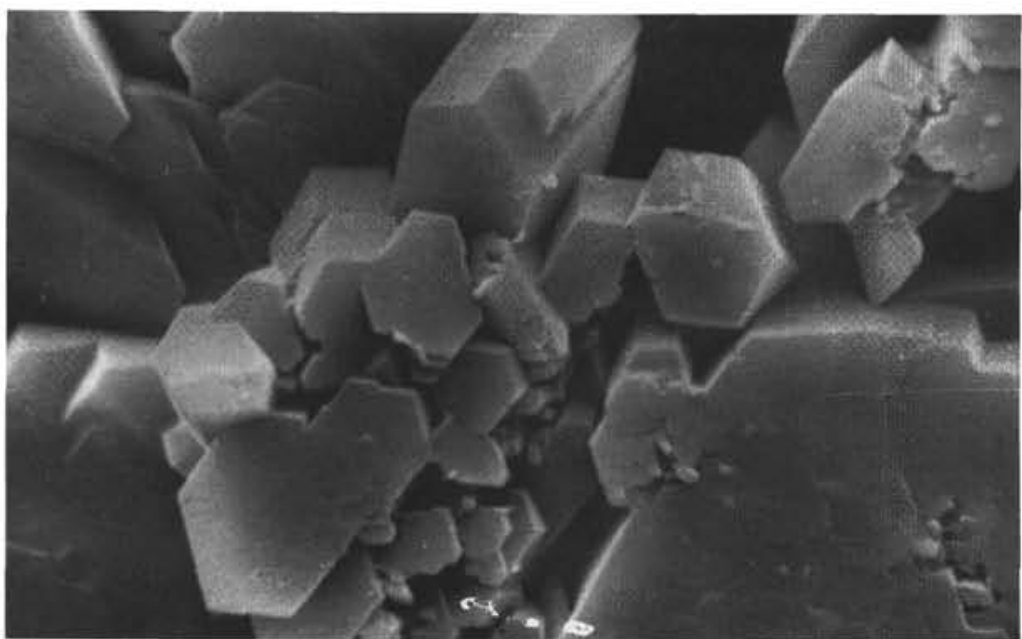

3

Plate 1. Scanning electron photomicrographs of secondary minerals in Sample 143-865A-94R$4,46-47 \mathrm{~cm}$ (Allison Guyot). $\quad 1$. Smectite replaces interstitial glass and single plagioclase crystal with cavity; magnification $1000 \times$. 2. Same as Figure 1 at $2000 \times$. 3. Kaolinite in cavity of plagioclase; magnification $4000 \times$. 


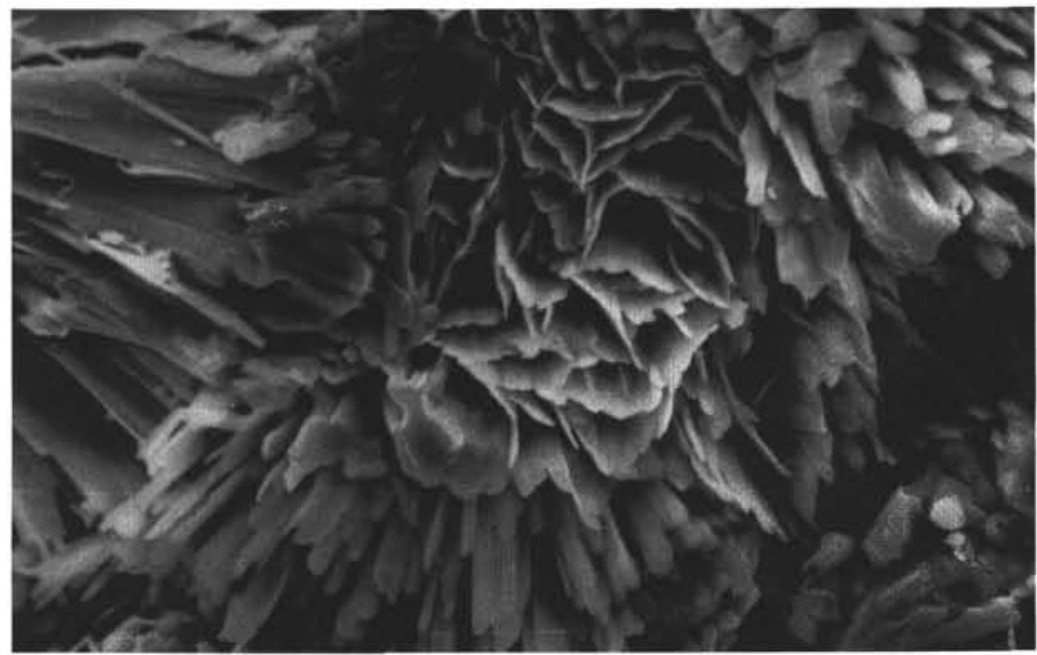

1

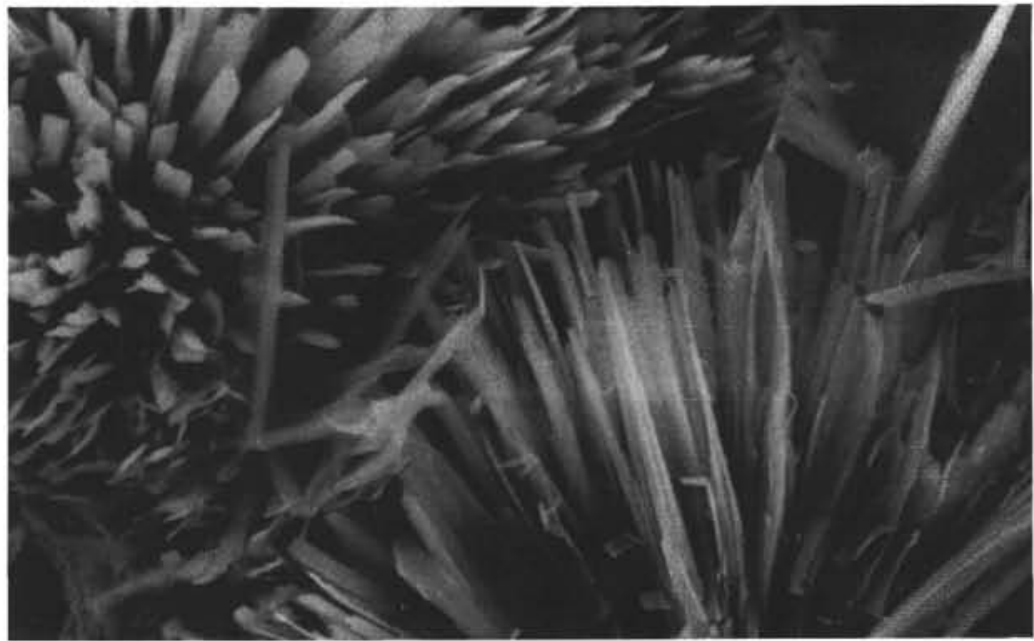

2

Plate 2. Scanning electron photomicrographs of smectite infilling vesicles in Sample 143-865A94R-4, 46-47 cm (Allison Guyot); magnification 4000x. 


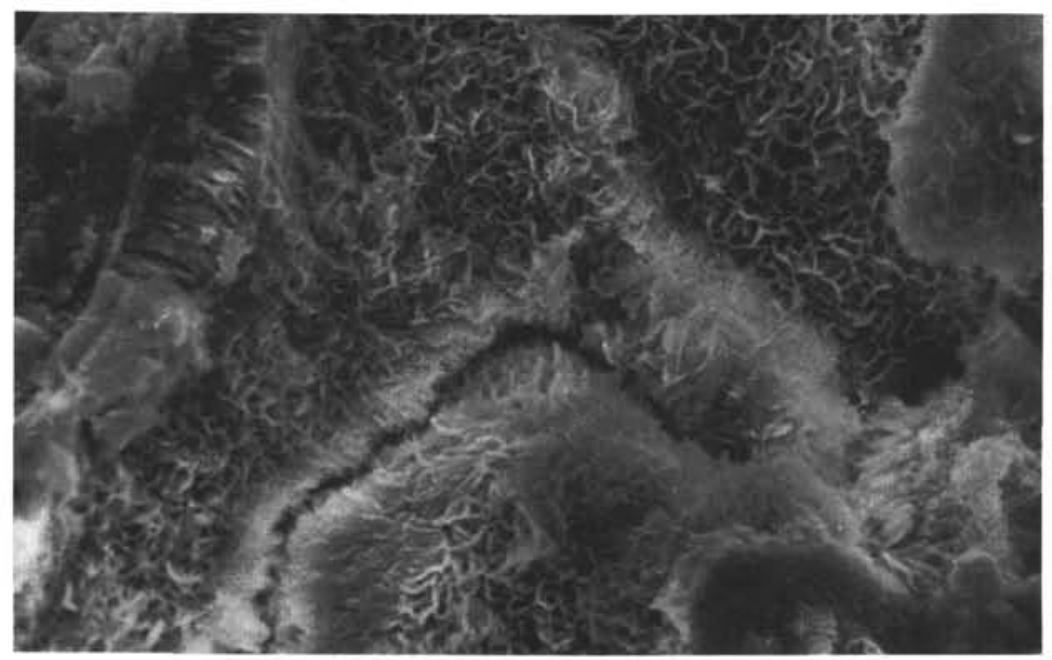

1

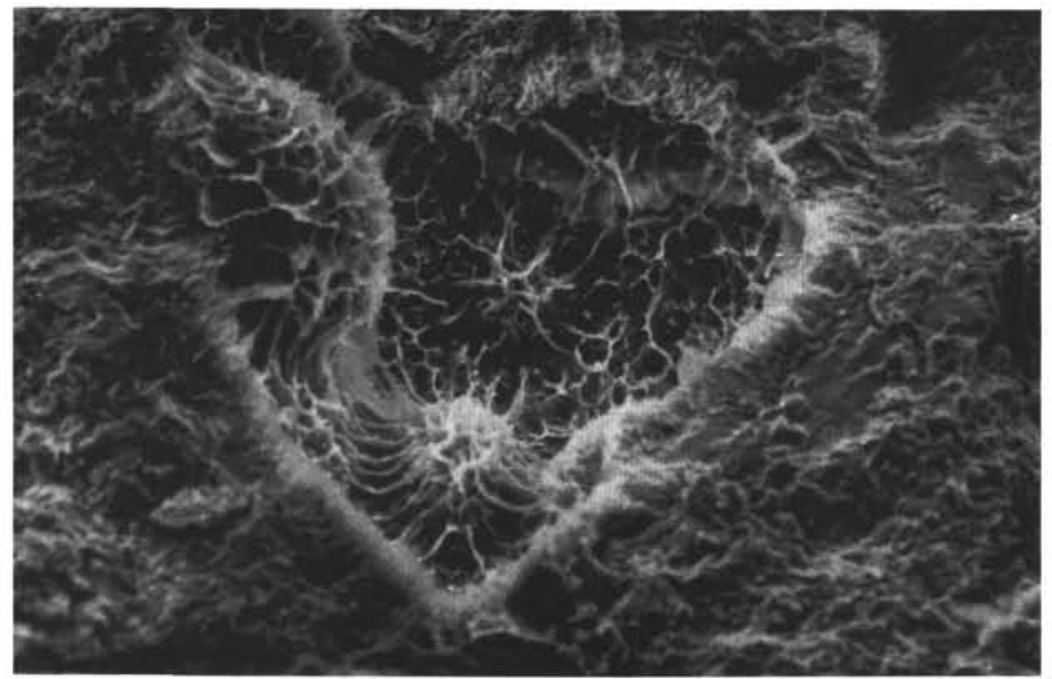

2

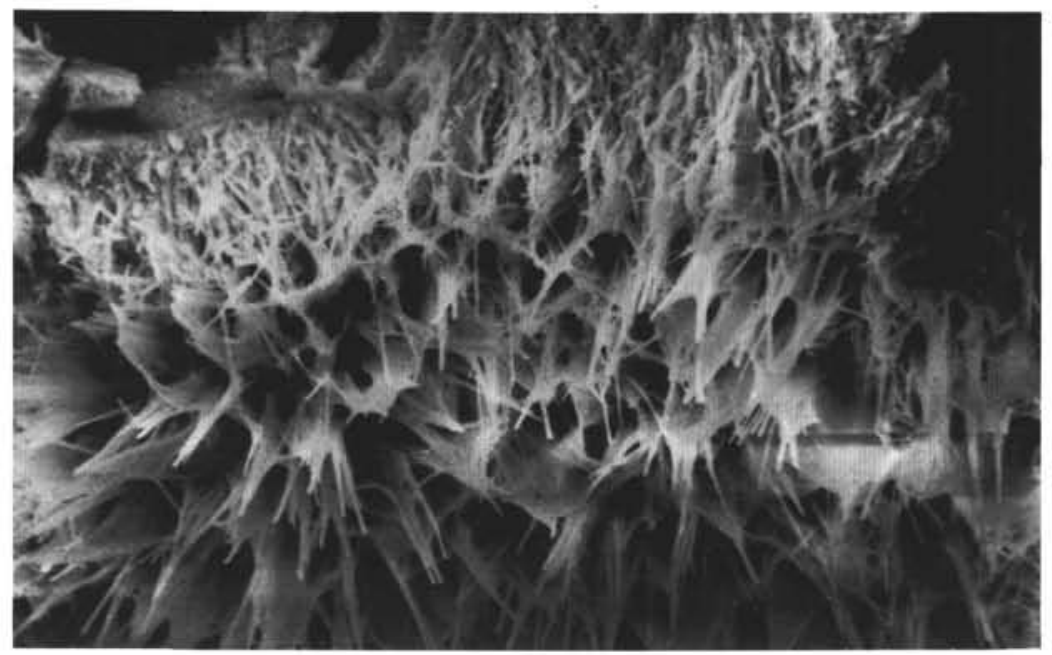

3

Plate 3. Scanning electron photomicrographs of secondary minerals at Hole 866A (Resolution Guyot). 1. Smectite replaces interstitial glass, Sample 143-866A-184R-2, 23-26 cm; magnification 1000x. 2. Smectite replaces olivine (pseudomorphs), Sample 143-866A-182R-4, 72-74 cm; magnification 4000X. 3. Smectite infilling vesicle, Sample 143-866A-184R-2, 23-26 cm; magnification 4000X. 